\title{
The Llamas de Cabrera gold district, a new discovery in the Variscan basement of northwest Spain: A fluid inclusion and stable isotope study
}

\author{
Fernando Gómez-Fernández ${ }^{\mathrm{a}}$, Elena Vindel ${ }^{\mathrm{b}, *}$, Tomás Martín-Crespo ${ }^{\mathrm{c}}$, Virginia Sánchez ${ }^{\mathrm{b}}$, \\ Emilio González Clavijo “, Roberto Matías ${ }^{\mathrm{e}}$ \\ a Área de Prospección e Investigación Minera, Universidad de León, C/Jesús Rubio 2, 24004, León, Spain \\ b Departamento de Cristalografia y Mineralogia, Facultad de Ciencias Geológicas, Universidad Complutense, 28040, Madrid, Spain \\ ' ESCET, E. Departamental II, Universidad Rey Juan Carlos, Móstoles, 28933, Madrid, Spain \\ "IGME. Unidad de Salamanca, C/Azafranal, 48, 37001, Salamanca, Spain \\ e Fundación Cultura Minera, CN-VI, Km. 366, Torre del Bierzo, 24370 Leôn, Spain
}

\section{Keywords:}

Gold

Fluid chemistry

Stable isotopes

Arsenopyrite geothermometer

Northwest Spain

\begin{abstract}
A B S T R A C T
The northwest of the Iberian Massif is well known to host numerous gold mineralizations which were exploited during Roman times. This study presents a multidisciplinary approach leading to the mineralogical, fluid inclusions, and geochemical characterization of the recently rediscovered Roman gold district of llamas de Cabrera. Gold occurs in extensional quartz veins hosted in the upper layers of the Lower to Middle Ordovician Armorican quartzite and occasionally in the overlaying Middle Ordovician slates from Luarca Formation. The veins are characterized by multistage ore deposition developed along three hydrothermal stages: $\mathrm{As}-\mathrm{Fe}(\mathrm{I}), \mathrm{As}-\mathrm{Fe}(\mathrm{II})$, and $\mathrm{Au}-\mathrm{Zn}-\mathrm{Cu}-\mathrm{Pb}$, followed by late supergene alteration processes. The fluid inclusion study undertaken on mineralized quartz revealed the presence of three types of fluids: (1) $\mathrm{CO}_{2}-\left(\mathrm{CH}_{4}\right)$ fluid inclusions, (2) aqueous-carbonic fluid inclusions dominated by $\mathrm{CO}_{2}$ and subordinate $\mathrm{CH}_{4}$ related to quartz-arsenopyrite-pyrite deposition, and (3) aqueous fluid inclusions related to the Au-sulfide deposition. In conjunction with arsenopyrite geothermometry and fluid-inclusion data an attempt was made to determine the P-T conditions of ore formation. Changes occurred in the P-T conditions from arsenopyrite and pyrite deposition in quartz veins from aqueous-carbonic fluids at $300-390^{\circ} \mathrm{C}$ and $200-220 \mathrm{MPa}$ towards $180-310^{\circ} \mathrm{C}$ and $<200 \mathrm{MPa}$ at the stage of gold from aqueous fluids. Mixing of two aqueous fluids of relatively contrasted salinity were favorable factors for decreasing gold solubility and could allow gold deposition. The $8^{34} S$ values are similar for the two As-Fe stages, $+8.0 \%$ to $+16.3 \%$ and $+9.0 \%$ to $+19.5 \%$ respectively, and for the post- $S_{1}$ pyrites from siliciclastic Luarca Formation suggesting a comparable sulfur source. Combining calculated $\mathbf{~}^{18} \mathrm{O}$ values of fluids of +6.7 to $+9 \%$ with fluid inclusion data indicates that fluids of unknown origin are largely equilibrated with metamorphic lithologies at medium-high temperatures. The ascent of some late Variscan magmatic bodies, not exposed at the present day erosion level, provides the heat source for convective water circulation. Gold quartz veins from Llamas de Cabrera display similar features and processes to related deposits of similar type elsewhere in the Variscan belt of western Europe (northwest and central/western Iberia, French Massif Central, Bohemian Massif). However Llamas de Cabrera shows certain differences, such as the non-appearance of igneous rocks in the area and the absence of Sb-rich minerals compared to some Variscan Sb-Au deposits, including northern, central, and western Iberia. This last could probably be due to a greater depth of formation for the As-Au veins in comparison to Sb-Au veins.
\end{abstract}

\section{Introduction}

The Iberian Massif is the southwest extension of the European Variscan Belt and one of the largest domains of the Variscan orogen. The northwest of the Iberia Massif was one of the most important

\footnotetext{
* Corresponding author. Tel.: +34 913944871; fax: + 34913944872

E-mail address: evindel@geo.ucm.es (E.Vindel)
}

gold producing areas during Roman times. Two types of mineralization, gold-quartz veins and alluvial deposits, were exploited between the first and third centuries when the region was part of the Roman Empire. Studies of these gold deposits have been made focusing on the archeological, geological, mineralogical, and geochemical aspects of the mineralization (Arias et al., 1997; Boiron et al., 1996; Crespo et al., 2000; Herail, 1984; Noronha et al., 2000; Ribera et al., 1992; Tornos et al., 1997), suggesting gold lodes genesis is related to convective hydrothermal cells re-equilibrated with metamorphic rocks. The district of Llamas de Cabrera has not previously been studied in detail. Although it was 
extensively mined by Roman miners it remained unknown unt 2002, when it was rediscovered by Matias and Gómez-Fernández (2003).

Mining in llamas de Cabrera district started in ancient times. The spectacular Roman mine workings in the northwest of the Iberian Peninsula have been the subject of several archeological studies (Pérez-Garcia et al., 2000; Sánchez-Palencia, 1983). About 500 historical mining sites have been recorded in this area and the total gold production during the first and second centuries has been established to be around $195 \mathrm{t}$, mainly from alluvial types, with an average gold grade of $67 \mathrm{mg} / \mathrm{m}^{3}$ and maximum of $1-2 \mathrm{~g} / \mathrm{m}^{3}$. From Roman times until the present, the gold mines in northwest Spain have remained inactive, except for small operations in the late nineteenth and first half of the twentieth centuries. However, since the increasing of gold prices in the 1970s, exhaustive prospecting was developed. The llamas de Cabrera district shows substantial ancient mine working, open pits, vertical pits, and galleries, with its own hydraulic network system (Gómez-Femández et al., 2005; Matias and Gómez-Fernández, 2003).

The primary gold ores of Llamas de Cabrera are located in locally post-deformation quartz veins hosted in the transition zone between the Armorican quartzite and the overlying black slates (Lower to Middle Ordovician). These deposits could be classified as the so-called "mesothermal" or "mesozonal" sulfide-poor gold-bearing quartz veins associated with regionally metamorphosed terranes of all ages (Groves et al., 1998). Widespread similar examples are found in Europe in relation to the Variscan orogen, for example the Massif Central of France (Boiron et al., 2003; Bouchot et al., 2005; Essaraj et al., 2001) and the Bohemian Massif (Boiron et al., 2001). These deposits were considered as orogenic vein gold deposits hosted in Late Proterozoic-Early Paleozoic metamorphic rocks and emplaced between 340 and $300 \mathrm{Ma}$. The northwest of the Iberian Peninsula gives a good opportunity to compare the characteris of Au-As veins with Au-Sb ore deposits located in Northwest and Central Iberia.

The present contribution (1) provides the first systematic description of Llamas de Cabrera gold district, (2) characterizes the hydrothermal ore-forming system through detailed fluid inclusion study, (3) analyses the compositional variation of arsenopyrite in order to be used as a geothermometer, (4) deduces information on possible sources of the mineralizing fluids and materials through stable isotope study, (5) reconstructs the P-T path of the history of the deposit, and (6) improves the knowledge of the auriferous veins of the northwest of the Iberian Peninsula. Finally, this paper synthesizes the main characteristics of the gold-bearing deposits of the Iberian Massif and compares to other similar deposits in western Europe.

\section{Geological setting}

According the division of the Iberian Variscan Massif (IVM) proposed in Pérez-Estaún et al. (2004), the studied area belongs to the Central Iberian Zone (CIZ), just in the limit to the West Asturian Leonese Zone (WALZ) (see Fig. 1.a inset). The gold mining works are placed along the northern limb of the Truchas Synform (Fig. 1.a) a complex structure formed by the coaxial interference of Variscan phase 1 and phase 3 events and several north-verging phase 2 thrust structures (Marcos, 1973; Pérez-Estaún, 1975; Rodríguez Fernández et al., 1982). Some of the complexities of this north limb are related to tight sub-vertical Variscan folds developed in Ordovician low grade metasediments and the underlying Cambrian-Ordovician igneous complex. These folds display axial plain related tectonic foliation showing that they were developed during Variscan phase 1 . Some trivial continental deposits (not represented in Fig. 1.a), related to the current fluvial net, quaternary glacial episodes, and slope avalanches, blanket the region locally. Nevertheless, some of these thin sedimentary bodies host quantities of gold and focused the mining works during Roman times (Herail, 1984; Matias and GómezFernández, 2003; Pérez-García et al., 2000).
The Palaeozoic sedimentary record spans all of the Ordovician System, displaying one of the most complete sequences in the $\mathrm{CIZ}$. Regionally, the Ordovician rocks overlie a voluminous igneous unit which crops extensively out to the South and East of the zone. This acidic igneous body is the oldest rock exposed in the region and is named "Ollo de Sapo" (Toad's Eye) Formation after a local name. It has been interpreted as a group of magmatic, volcanic, and volcanosedimentary rocks of uppermost Cambrian and low Ordovician age (Diez Montes et al., 2010). It is gradually overlaid by a thick succession of phyllite and quartzite which becomes more enriched in the sandy term towards the top, ending in a decametre-thick bed of white quartzite (Armorican type). Trace fossils found in the area validate the Lower Ordovician age of this formation (Martínez Catalán et al., 1992). The Middle Ordovician is made of a characteristic unit of black slates. The transition between the Armorican quartzite type levels and the black slates is gradual, and some authors distinguish a transitional series locally, called Rubianes Formation in the region (Gutiérrez-Marco et al., 1999), which is formed by layers of quartzite, slate, and oolitic iron and hosts most of the mineralized bodies studied here. The Upper Ordovician sequence lies unconformably and starts with the "La Aquiana" limestone. The rest of the Upper Ordovician was divided by Barros Lorenzo (1989) into three dewital formations: Casaio, Rozadais, and Losadilla from bottom to top.

The poly-phase Variscan tectono-metamorphic processes affected the entire IVM. In the Truchas Syncline North limb no other tectonic foliation than the Variscan phase 1 was identified, suggesting that the mineralized veins are younger than this foliation. Variscan magmatic bodies of any phase are not exposed in the work area. But towards the south and east, in the "Ollo de Sapo" antiform, diverse Variscan granitoides are exposed. They include early syn-kinematic, syn-kinematic mesozonal, syn-kinematic epizonal, and post-kinematic epizonal granitoides related to a metamorphic core complex (Díez Montes et al., 2010). At present-day surface level the grade of regional metamorphism is low (chlorite zone) in the Ordovician sequence rocks. According Diez Montes (2007) the metamorphism is coeval to the Variscan phase 1 , reaching its peak towards the end of this phase. The same author established a different metamorphic history for the "Ollo de Sapo" formation (structurally deeper during the Variscan) with a higher metamorphic peak during the late Phase 2 and a retrograde subsequent evolution related to the thermal doming processes associated to the formation of a metamorphic core complex.

\section{Vein features}

llamas de Cabrera gold district constitutes an extensive area $(45 \times 20 \mathrm{~km})$ which contains several occurrences of quartz-arsenopyrite gold veins (Fig. 1). The ore deposits are structurally controlled and could be grouped in three types (Table 1): (1) N-S to $\mathrm{N} 20^{\circ}$ E extensional quartz veins, (2) quartz veins, brecciated structures, and stockworks along WNW-ESE, and (3) other ore are related to NE-SW faults. They are hosted in the upper layers of the Lower to Middle Ordovician Armorican quartzite facies (Fig. 3a), equivalent to Rubianes Formation. Occasionally mineralized quartz veins have been likewise recognized in Middle Ordovician slates from the Luarca Formation (Fig. 3b).

The highest density of quartz veins appears in the western part of the district, in the llamas de Cabrera area, within a $75 \times 450 \mathrm{mE}-\mathrm{W}$ segment. The set of sub-parallel veins displays preferably N-S orientation (Zone $\mathrm{B}$ and $\mathrm{C}$ ), as well as $\mathrm{N} 124^{\circ} \mathrm{E}$ in Zone $\mathrm{A}$ with a sub-vertical dip ranging from 75 to $85^{\circ}$. The veins filled by milky quartz are up to $0.5 \mathrm{~m}$ thick. These veins show all the characteristics of dilational veins, and especially do not show any shearing of fracture fill. Mineralized tectonic breccias structures are characteristics of major WNW-ESE and NE-SW faults in A Zone and in the Pombriego deposit (Fig. 3c). The Valdecorrales area displays mining activity along $325 \mathrm{~m}$ trending $\mathrm{N}$ $70^{\circ}$ E. Pombriego and Tabuyo del Monte show minor mining activity constituting narrow mineralized areas along $\mathrm{N} 120^{\circ} \mathrm{E}$ and $\mathrm{N} 130^{\circ} \mathrm{E}$ 


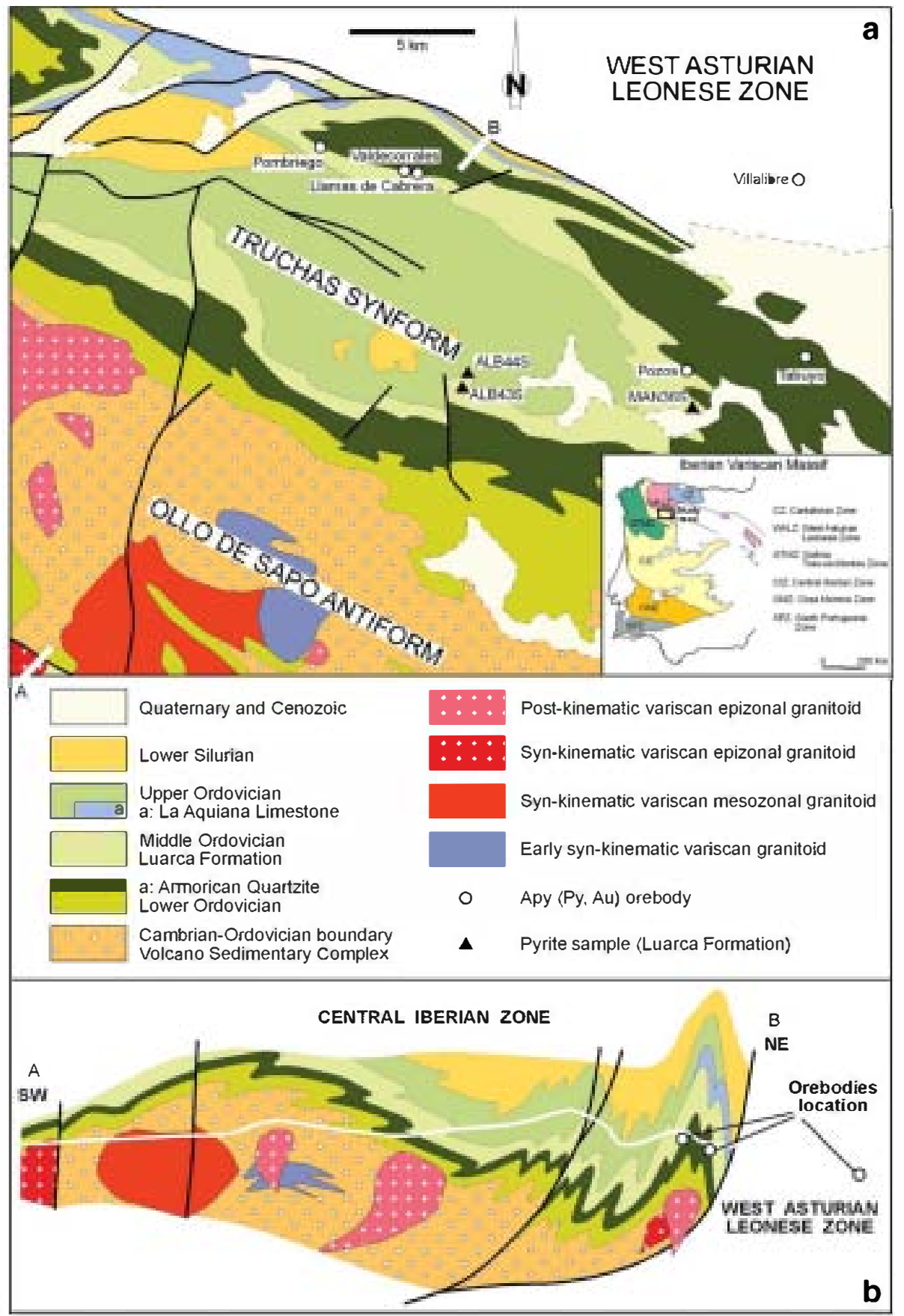

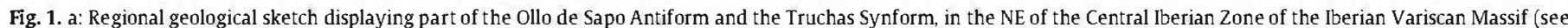

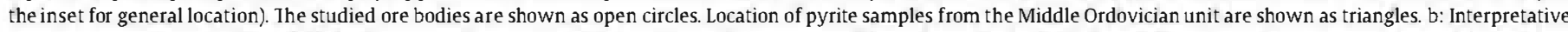

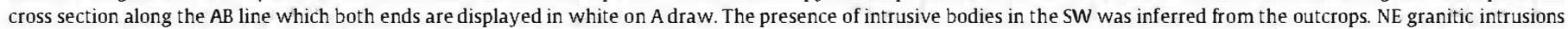
were deduced as the plausible thermal source necessary for the mineralization systems.

faults respectively. Pozos is characterized by the presence of unexploited stockworks on both sides of a major $\mathrm{N} 120^{\circ} \mathrm{E}$ fault zone (Table 1 ).

Hydrothermal alteration, including silicification, chloritization, and sericitization, have been observed in the enclosing rocks. Disseminated mineralization is present in hydrothermally altered zones on both sides of the veins $( \pm 1 \mathrm{~m})$.

\section{Sampling and analytical procedures}

For this study, samples of quartz and ore minerals from several deposits of Llamas de Cabrera district: Valdecorrales, Llamas de Cabrera A, B, and C, Pombriego, Villalibre, Pozos, and Tabuyo del Monte, were collected on surface mine exposures. The characteristics of these veins are summarized in Table 1.

Compositional analyses of sulfides (arsenopyrite, pyrite, bismuthinite, sphalerite, chalcopyrite, pyrrhotite, tetrahedrite, galena) were carried out using an electron microprobe (JEOL Superprobe JXA-8900 M) employing wavelength dispersive spectrometry at the Luis Brú Microscopy Centre (Universidad Complutense de Madrid). The diameter of the electron beam was $5 \mu \mathrm{m}$ and all determinations were performed at a potential of $50 \mathrm{kV}$ for sulfides and a beam current of $30 \mathrm{nA}$. The following minerals were used as standards: galena, anglesite, nickeline, AsGa, HR-160 (Co-Ni-Cr), chalcopyrite, $\mathrm{Zn}, \mathrm{Mo}, \mathrm{Ag}, \mathrm{Cd}, \mathrm{Sb}, \mathrm{Bi}_{2} \mathrm{Te}_{3}$, cinnabar, and hutchinsonite. 
Table 1

Main geological and mineralogical features of gold veins, Llamas de Cabrera district (from W to E).

\begin{tabular}{|c|c|c|c|c|c|}
\hline Deposit & Vein location & Orientations of veins & Country rock & Ore mineralogy & Other characteristics \\
\hline Pombriego & & $\begin{array}{l}\text { Along a } \mathrm{N} 120^{\circ} \mathrm{E} / 74^{\circ} \mathrm{S} \\
\text { fault }\end{array}$ & Quartzite (Iower to Middle Ordovician) & $\begin{array}{l}\text { Qz, Apy, Py, Po, Gn, Ccp, } \\
\text { Au, Ttr }\end{array}$ & Tectonic breccia \\
\hline \multirow[t]{4}{*}{ Llamas de Cabrera } & Valdecorrales & Along a N70E fault & Quartzite (Iower to Middle Ordovician) & Qz, Apy, Py, Gn, (Au) & $\begin{array}{l}\text { Veinlets and tectonic breccias related } \\
\text { to a NE-SW fault. }\end{array}$ \\
\hline & A Zone & $\mathrm{N} 124^{\circ} \mathrm{E} / 75^{\bullet} \mathrm{N}$ & $\begin{array}{l}\text { Quartzite, sandstone and slate (Iower to } \\
\text { Middle Ordovician) }\end{array}$ & $\begin{array}{l}\text { Qz, Apy, Py, Sp, Gn, Au, } \\
\text { Ccp, Po, Bis }\end{array}$ & $\begin{array}{l}\text { Related to NW-SE "La Patadura" fault. } \\
\text { Tectonic breccia }\end{array}$ \\
\hline & B Zone (El Zanjón) & $\mathrm{N} 175^{\bullet} \mathrm{E} / 85^{\bullet} \mathrm{N}$ & & & Individual quartz vein \\
\hline & C Zone & $\mathrm{N}-\mathrm{S} / 80^{\circ} \mathrm{E}$ & & & $\begin{array}{l}\text { More than twenty } \mathrm{N}-\mathrm{S} \text { mineralized } \\
\text { quartz veinlets } \mathrm{E}-\mathrm{W} \text { aligned }\end{array}$ \\
\hline Pozos & & $\begin{array}{l}\text { Along a } \mathrm{N} 120^{\circ} \mathrm{E} / 80-90^{\circ} \\
\text { fault }\end{array}$ & $\begin{array}{l}\text { Quartzite and slate (Lower to Middle } \\
\text { Ordovician) }\end{array}$ & $\begin{array}{l}\text { Qz, Apy, Py, Au, Sp, Gn, } \\
\text { Ccp, Po, Ttr, Cin* }\end{array}$ & Stockwork \\
\hline Ermita de Villalibre & & $\mathrm{N} 18^{\circ} \mathrm{E} / 80^{\circ} \mathrm{W}$ & $\begin{array}{l}\text { Quartzite and slate (Middle Cambrian } \\
\text { to Iower Ordovician) }\end{array}$ & Qz, Apy, Py, (Au) & Quartz veinlets aligned WNW-ESE \\
\hline Tabuyo del Monte & & $\begin{array}{l}\mathrm{N} 145^{\circ} \mathrm{E} / 40^{\circ} \mathrm{N} \text { and } \\
\mathrm{N} 130^{\circ} \mathrm{E} / 50^{\circ} \mathrm{S}\end{array}$ & Quartzite (Iower to Middle Ordovician) & Qz, Apy, Py, (Au) & Set of quartz veinlets \\
\hline
\end{tabular}

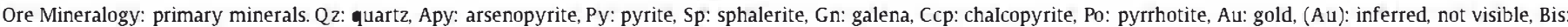
bismuthinite, Ttr: tetrahedrite, ${ }^{*}$ cin: cinnabar from Tornos et aL (1997).

Microthermometric studies of fluids inclusions (86 from 15 samples) were carried out on doubly polished wafers $(300 \mu \mathrm{m})$ with a Linkam THMSG 600 heating-freezing stage (Shepherd, 1981). The stage was calibrated based on the melting point of solid standards at $\mathrm{T}>25{ }^{\circ} \mathrm{C}$ and natural and synthetic inclusions at $\mathrm{T}<0{ }^{\circ} \mathrm{C}$. The rate of heating was monitored in order to obtain measurement precision of $\pm 0.2^{\circ} \mathrm{C}$ during freezing and $\pm 1{ }^{\circ} \mathrm{C}$ when heating within the $25-400{ }^{\circ} \mathrm{C}$ temperature range. The salinity of $\mathrm{H}_{2} \mathrm{O}-\mathrm{NaCl}$ inclusions reported as equivalent weight percent $\mathrm{NaCl}$ ( $w t . \% \mathrm{NaCl}$ equiv.) was calculated from microthermometric data (ice melting, $\mathrm{T}_{\mathrm{m}, \mathrm{ice}}$ ) using the equations from Bodnar (1993). Bulk composition and molar volumes were computed from $\mathrm{P}-\mathrm{V}-\mathrm{T}-\mathrm{X}$ properties of individual inclusions in the $\mathrm{C}-\mathrm{O}-\mathrm{H}-(\mathrm{N}-\mathrm{S})$ system (Bakker et al., 1996; Thiery et al., 1994) using an estimate of the $\mathrm{NaCl}$ content but neglecting the effect of sulfate content. The P-T properties of aqueous-carbonic inclusions were modeled using the equation of state of Bakker (1999) for the $\mathrm{H}_{2} \mathrm{O}-\mathrm{NaCl}-\mathrm{CO}_{2}-\mathrm{CH}_{4}$ system and data from Zhang and Frantz (1987) for the $\mathrm{H}_{2} \mathrm{O}-\mathrm{NaCl}$ system. The analysis of the gas phase composition of individual inclusions was performed on a Jobin Yvon T64000 multichannel modular micro-Raman spectrometer following the procedure given by Burke (2001) and analyses of the relative amounts of $\mathrm{CO}_{2}$ and $\mathrm{CH}_{4}$. Analyses were performed at the Serveis Cientificotècnics of the Universitat de Barcelona (Spain).

Twenty-seven quartz samples were analyzed for ${ }^{18} \mathrm{O} /{ }^{16} \mathrm{O}$ at the Servicio General de Isótopos Estables of Salamanca University (Spain) using a laser fluorination procedure, involving total sample reaction with excess $\mathrm{ClF}_{3}$ (Borthwick and Harmon, 1982) using a $\mathrm{CO}_{2}$ laser as a heat source (in excess of $1500^{\circ} \mathrm{C}$; following Sharp, 1990). This $\mathrm{O}_{2}$ was then converted to $\mathrm{CO}_{2}$ by reaction with hot graphite (Clayton and Mayeda, 1963) and then analyzed on-line by a VG-Isotech SIRA-II mass spectrometer. Reproducibility is better than $\pm 0.3 \%$ 。 $(1 \sigma)$, based on repeat analyses of intemal and international standards during sample runs. Results are reported in standard notation $\left({ }^{18} \mathrm{O}\right)$ as per mil (\%) deviations from the VSMOW standard.

Sulfur isotope analyses were performed on 13 arsenopyrites, 8 pyrites, and 3 sphalerites. Analyses were performed at the Servicio General de Isótopos Estables of Salamanca University (Spain) by standard techniques (Robinson and Kusakabe, 1975) in which $\mathrm{SO}_{2}$ gas was liberated by combusting with excess $\mathrm{Cu}_{2} \mathrm{O}$ at $1075^{\circ} \mathrm{C}$, in vacuo. liberated gases were analyzed on a VG Isotech SIRA II mass spectrometer, and standard corrections applied to raw $\delta^{66} \mathrm{SO}_{2}$ values to produce true $\delta^{34} \mathrm{~S}$ values. The standards employed were the intemational standards NBS-123 or NBS-127. These gave $\delta^{34} S$ values of $+17.1 \%,-31.5 \%$, and $-4.6 \%$ respectively, with $1 \sigma$ reproducibility better than $\pm 0.2 \%$. Data are reported in $\delta^{34} S$ notation as per mil (\%) variations from the Vienna Canyon Diablo Troilite (V-CDT) standard.

\section{Mineralogy and paragenesis}

The mineralogy of the different studied veins is summarized in Table 1 and the paragenetic sequence is given in Fig. 2. The veins are characterized by multistage ore deposition belonging to three primary mineralizing stages and a supergene alteration stage.

\subsection{Ore stage I: As-Fe (I)}

During the first ore stage fractures affecting the silicified (microcrystalline quartz), sericitizated (Fig. 3d), and local chloritizated host rocks were filled by quartz, arsenopyrite, and pyrite. Milky quartz $\left(Q_{z}\right.$ I) forms aggregates of medium-grained crystals with serrate contacts (Fig. 3d). The quartz crystals exhibit undulose extinction of large rounded to irregularly shaped crystals cemented by a mass of fine quartz grains. Quartz I, the main mineral of the veins, contains abundant small (generally $<5 \mu \mathrm{m}$ ) fluid inclusions and hosts all later mineralization. Arsenopyrite I and pyrite I are the earliest sulfides to be formed. Arsenopyrite is the most common sulfide in the veins and it occurs as massive or as sub-euhedral crystal aggregates during stage L Pyrite I is rare and occurs intergrown with arsenopyrite $\mathrm{L}$

\subsection{Ore stage II: As-Fe (II)}

The intermediate stage is characterized by the presence of a second quartz, arsenopyrite, and pyrite generation. A brittle deformation phase is recognizable from cataclastic textures of arsenopyrite (Figs. 3e and 4c), pyrite I, and quartz I, and development of microfractures healed by subsequent ore minerals.

Clear quartz ( $Q z$ II) can be observed in the central part of the veins, sometimes having euhedral terminations, and cementing arsenopyrite I (Fig. 3e). The second generation of arsenopyrite II is characterized by euhedral or sub-euhedral rhombs intergrown with pyrite II. No compositional differences were recognized between pyrite I and II (Table 2). Arsenopyrite II is strong zoned with significant variations in As content. Although this compositional zoning cannot be recognized optically, it is easily recognized in back-scattered electron images. Arsenopyrite II is intergrown intimately with a second generation of pyrite (Fig. 4a). Occasionally, scattered pyrite and arsenopyrite porphyroblasts of the second generation can be recognized in slates crosscutting $S_{1}$ schistosity. They developed pressure shadows showing syntectonic structures of feather quartz and fibrous muscovite (Fig. 3f). These textural relations indicate the simultaneous equilibrium crystallization of arsenopyrite II with pyrite II. Scarce grains of bismuthinite are recognized in pyrite from this stage. 


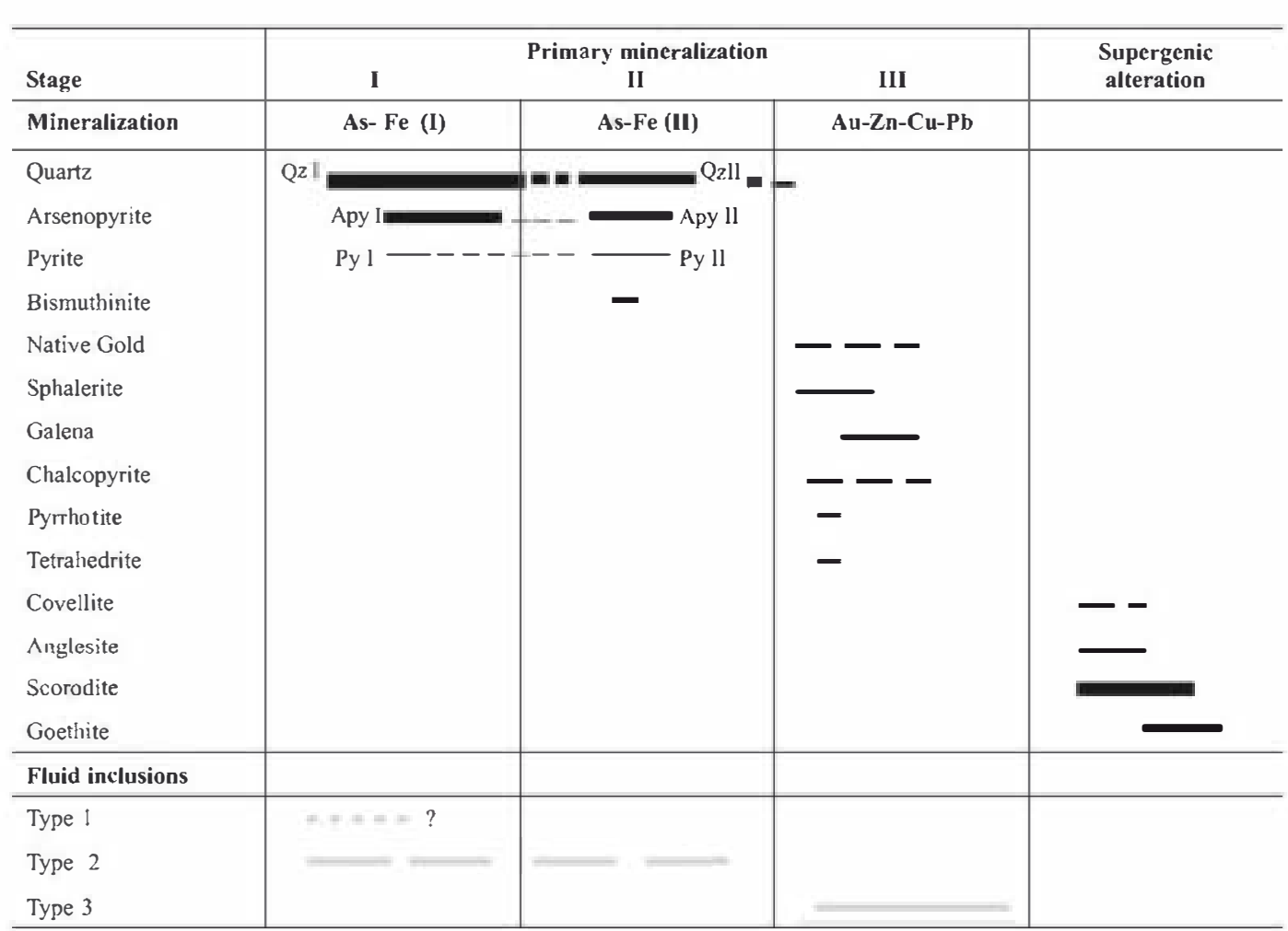

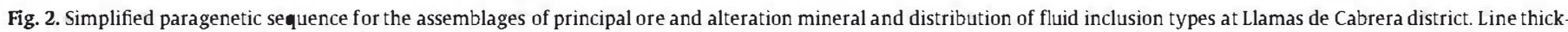

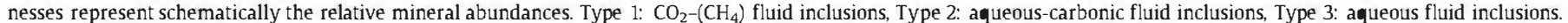

\subsection{Ore stage III: $\mathrm{Au}-\mathrm{Zn}-\mathrm{Cu}-\mathrm{Pb}$}

The third stage is characterized by the cogenetic crystallization of gold, sphalerite, galena, chalcopyrite, tetrahedrite, and pyrrhotite filling microfissures crosscutting the earlier stages of quartz and earlier sulfides. Galena is mainly later than sphalerite, as it partially surrounds sphalerite (Fig. 4b). Chalcopyrite contains inclusions of pyrrhotite and tetrahedrite. Microprobe analyses revealed that tetrahedrite could be considered as freibergite because of its relatively high Ag content (24.33wt.\%). Average composition of sulfides minerals from stage III are shown in Table 2 .

Native gold is found as anhedral grains, ranging from $1.3 \mu \mathrm{m}$ to a few micrometers to (long axis) in size, in cracks affecting previous As-Fe sulfides from ore stage I and II (Fig. $4 \mathrm{c}$ and d). Coexistence of native gold with other sulfides can be observed (Fig. 4c). Inclusions of gold are rarely found in quartz. Gold composition was determined in a previous study (Gómez-Fernández et al., 2005), with Au ranging between 91.44 and 95.14 wt.\%, Ag between 1.99 and 7.62 wt.\%, and minor amounts of As (less than $0.08 w t . \%)$, Fe (0.50-0.9wt\%), S (0.06-0.12wt.\%), Te (0.05-0.14 wt.\%), Bi (0.12-0.27 wt.\%), and Zn (less than 0.04 wt.\%). Cu content is below the detection limit. Quartz associated with gold is insignificant, implying a reduced supply of silica to the system.

\subsection{Supergene mineralization}

Early mineral assemblages are locally replaced by supergene covellite (Table 2), anglesite, goethite, and especially scorodite replacing arsenopyrite (Fig. $4 \mathrm{c}$ and d). This low-temperature alteration assemblage is found in complex sets of micro-cracks that crosscut the primary minerals.

\section{Composition of arsenopyrite}

Over 80 spot analyses were made on arsenopyrites I and II and several grains were analyzed in the same polished section. Average composition of arsenopyrites are shown in Table 3. Arsenopyrite grains from Llamas de Cabrera are subtly zoned, showing that the centers of arsenopyrite crystals are S-rich relative to the rims. The existence of zoning reflects minor changing conditions during arsenopyrite growth and attests to the strong resistance of arsenopyrite to internal homogenization. Because of this refractory nature, arsenopyrite composition reflects formation temperature (Kretschmar and Scott, 1976). Arsenopyrite geothermometer should be used with caution (Kerestedjian, 1997; Sharp et al., 1985); however, in conjunction with fluid inclusion data it could provide an estimate of formation temperatures.

The As content of the first generation of arsenopyrite (Apy I) shows a compositional range between 28.3 and $30.9 \mathrm{wt} . \%$ and the range of As content of the second generation of arsenopyrite (Apy II) is slightly lower, between 27.2 and 30 wt.\% (Fig. 5). Representative values of Fe content are 36.07 and 36.23 wt.\% for Apy I and between 35.62 and 36.47 wt.\% for Apy II. Total concentration of $\mathrm{Ni}$ and $\mathrm{Co}$ is small and does not exceed 0.1 wt.\% for Apy I and 0.5 wt.\% for Apy II. Other elements show similar values for both types of arsenopyrites (Table 3). The slight differences between arsenopyrites from stages I and II imply similar conditions during the formation of the two stages. Arsenic and sulfur are strongly negatively correlated (Fig. 5) following the classical substitution: $\mathrm{FeAs}_{1 \pm x} \mathrm{~S}_{1 \pm x}$.

\section{Fluid characterization}

\subsection{Petrography, distribution, and types}

Gold quartz veins of llamas de Cabrera district are devoid of good material for fluid inclusion studies due to the presence of quartz containing only very tiny fluid inclusions. For this reason, systematic sampling of distinct paragenetic stage for detailed fluid inclusion study was not feasible and only some coarsely crystalline quartz I and II were suitable for microthermometric analysis. The distribution of the fluid inclusions is similar in the two types of quartz. 

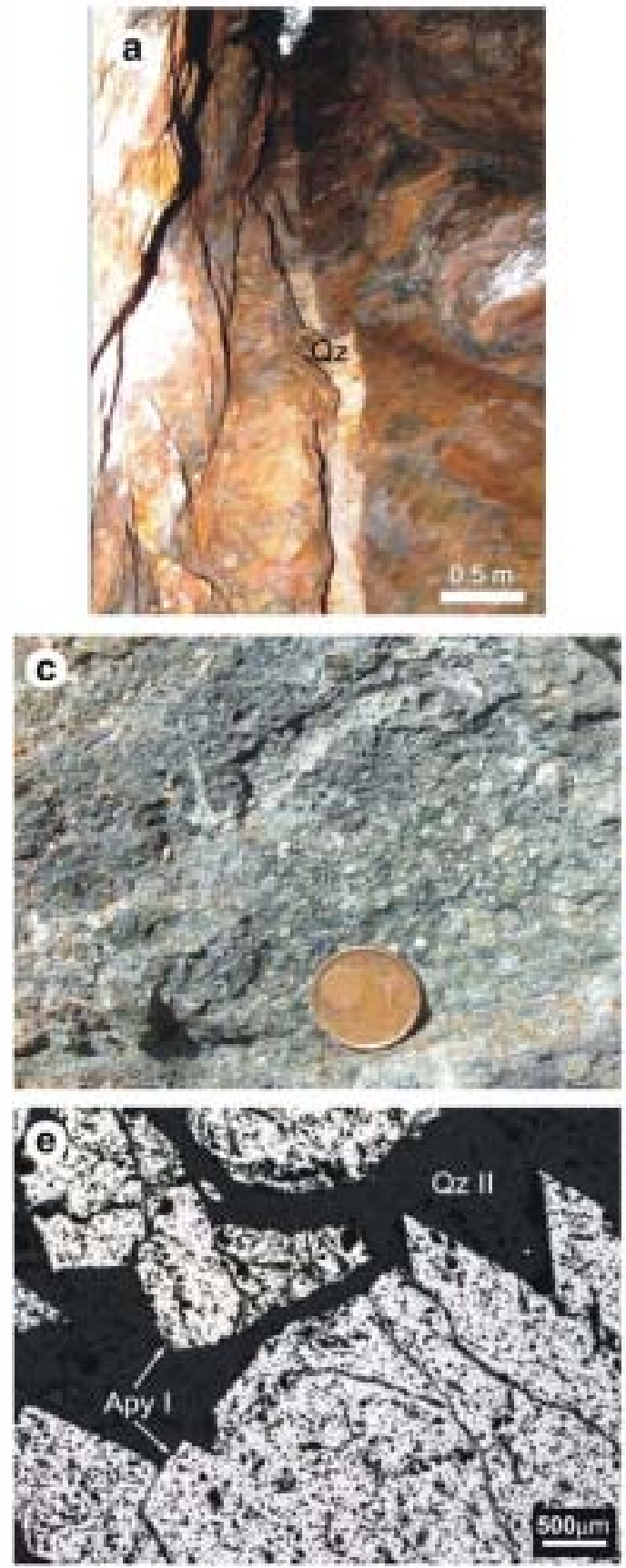
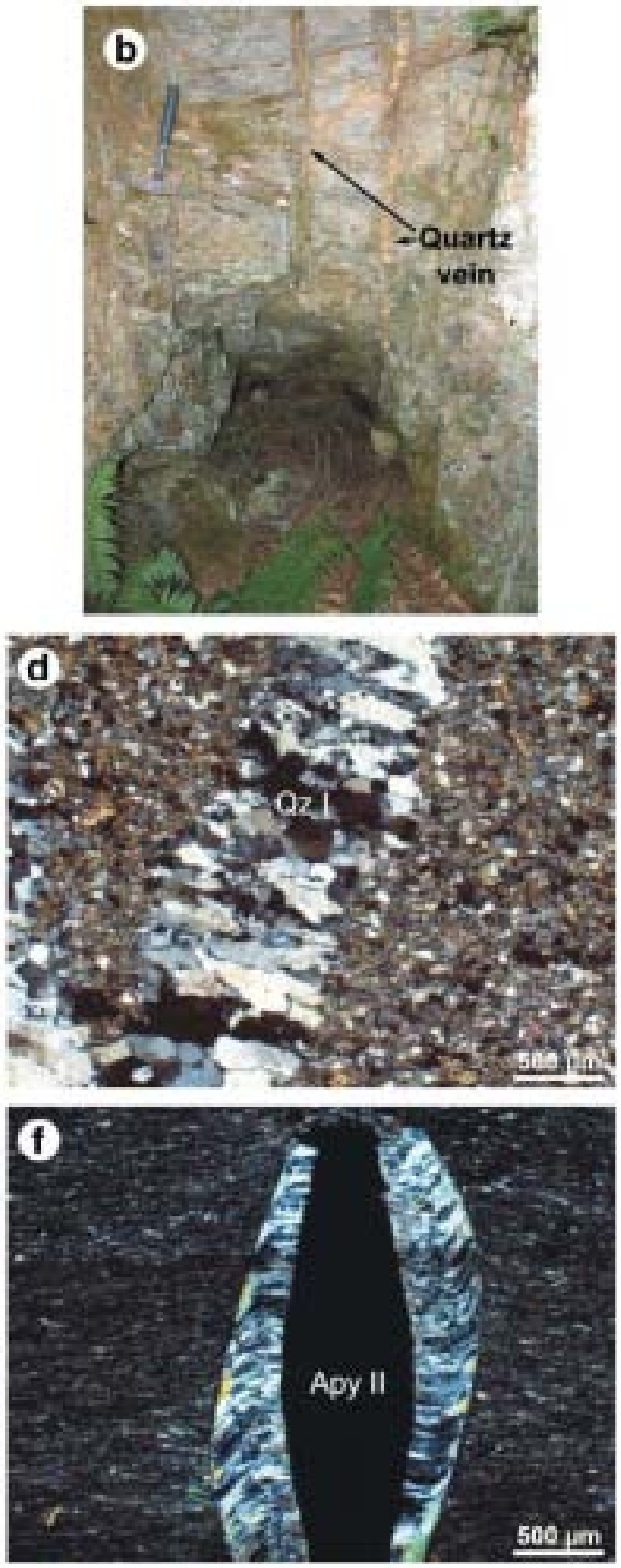

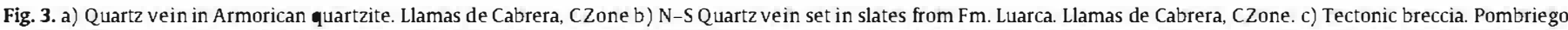

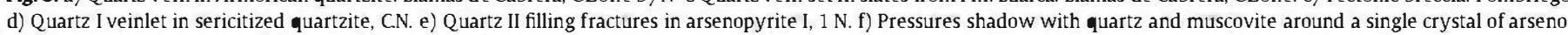
pyrite II, C.N. Apy: arsenopyrite, Py: pyrite, Qz: quartz.

Three different compositional types of fluid inclusions are distinguished based on their optical characteristics at room temperature and on microthermometric behavior during cooling and heating experiments. Type 1 (carbonic fluid inclusions) consists of two-phase inclusions lacking visible $\mathrm{H}_{2} \mathrm{O}$ at room or sub-zero temperatures, showing a $\mathrm{VCO}_{2}$ of 0.10 to 0.40 (visual estimate at $25^{\circ} \mathrm{C}$ ). These inclusions are scarce and have only been recognized in the first quartz generation $(\mathrm{Qz} \mathrm{I})$ from Valdecorrales deposit, ranging from 5 to $10 \mu \mathrm{m}$ in size. Type 2 inclusions $\mathrm{H}_{2} \mathrm{O}-\mathrm{NaCl}-\mathrm{CO}_{2}-\left(\mathrm{CH}_{4}\right)$ are three-phase at room temperature $\mathrm{CO}_{2}$-bearing inclusions (Fig. 4e), with a dark two fold gaseous bubble and a clear liquid phase with a variable gas/liquid ratio of $0.08-0.40$, varying in size between 5 and $15 \mu \mathrm{m}$. Type 3 are two-phase (Fig. 4f) and $\mathrm{H}_{2} \mathrm{O}$-rich inclusions $\left(\mathrm{H}_{2} \mathrm{O}-\mathrm{NaCl}\right.$ inclusions) with small vapor bubbles $(<30 \%)$. These inclusions are abundant and generally relatively small $(<5$ to $10 \mu \mathrm{m}$ ), showing a variety of shapes ranging from irregular to rounded and ellipsoidal shapes.

Repeated fracturing and healing make it difficult to constrain a precise timing of the different fluid inclusion types relative to the gold event. However, in some cases, detailed petrographic investigations allowed a relative chronology of inclusions to be established using the criteria of Roedder (1984, p.12-45). Most Type 1 and Type 2 inclusions are isolated and regular in shape in quartz (Type I inclusions only in $\mathrm{Qz} I$ ), suggesting that they could represent early fluids. Presumable re-equilibration of Type I fluid inclusions will be discussed in Section 9. Type 3 are undoubtedly secondary inclusions in relation to the two types of quartz, because they crosscut clusters of 

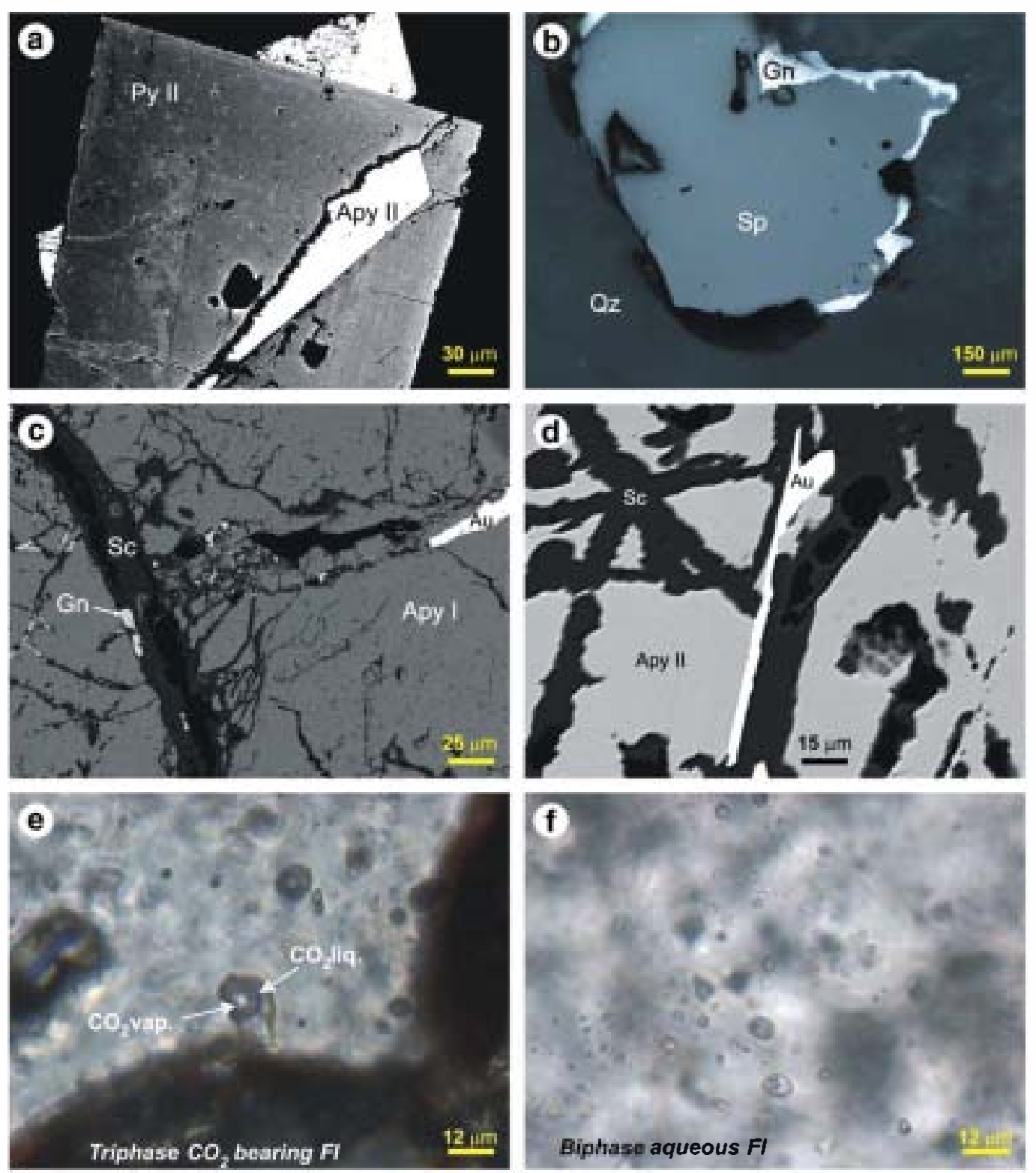

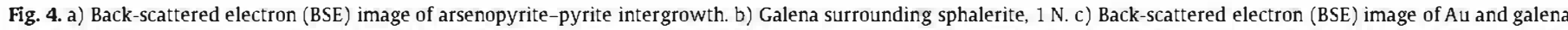

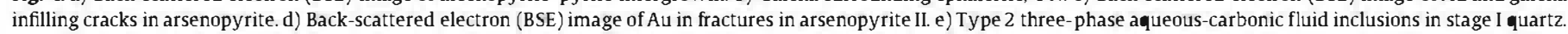
f) Type 3 two-phase aqueous fluid inclusions in stage I quartz. Apy: arsenopyrite, Sp: sphalerite, Gn: galena, Sc: scorodite.

earlier aqueous-carbonic fluid inclusions or occur along healed traces of microfractures cutting the quartz boundaries. Type 3 inclusions represent a later aqueous fluid after quartz deposition. Relative chronology between fluid inclusion types and ore deposition is shown in Fig. 2.

\subsection{Microthermometric and micro-Raman results}

Microthermometric data are summarized in Table 4 with all abbreviations used in the text.

Three different types of fluids have been recognized during the microthermometric work and several runs have been undertaken down to the lowest limit of temperature of the heating-freezing stage $\left(\sim 180^{\circ} \mathrm{C}\right)$, in order to detect the presence of $\mathrm{CH}_{4}$ and/or $\mathrm{N}_{2}$. However, all inclusions are frozen between -100 and $-120^{\circ} \mathrm{C}$, indicating that these compounds are not present in significant amounts.

After heating from these low temperatures, the melting of $\mathrm{CO}_{2}$ $\left(\mathrm{T}_{\mathrm{m}} \mathrm{CO}_{2}\right)$ in carbonic fluid inclusions (Type 1 ) occurred in a relatively narrow interval, between -58.4 and $-57{ }^{\circ} \mathrm{C}$ indicating minor amounts of $\mathrm{CH}_{4}$, and the homogenization of carbonic phases $\left(\mathrm{T}_{\mathrm{h}} \mathrm{CO}_{2}\right)$ into liquid occurred from 4.4 to $12.0^{\circ} \mathrm{C}$, corresponding to high $\mathrm{CO}_{2}$ densities of 0.9 to $0.85 \mathrm{~g} / \mathrm{cm}^{3}$. Formation of clathrates was not observed in type 1 fluid inclusions, which was expected given the absence of visible water in the inclusions.

$\mathrm{T}_{\mathrm{m}} \mathrm{CO}_{2}$ in aqueous-carbonic fluid inclusions (Type 2) ranges between -58.4 and $-56.7{ }^{\circ} \mathrm{C}$ and $\mathrm{T}_{\mathrm{h}} \mathrm{CO}_{2}$ between 20.7 and $29.3^{\circ} \mathrm{C}$ to either liquid or vapor phase $\left(\mathrm{CO}_{2}\right.$ densities of $\left.0.62-0.76 \mathrm{~g} / \mathrm{cm}^{3}\right)$. The clathrate melting temperature $\left(\mathrm{T}_{\mathrm{m}} \mathrm{Cl}\right)$ is between 7.8 and $9.3^{\circ} \mathrm{C}$, indicating salinities of around 1.4 to $4.1 \mathrm{wt} \% \mathrm{NaCl}$ equiv. Total homogenization of aqueous-carbonic fluid inclusions to liquid occurs between 285 and $360{ }^{\circ} \mathrm{C}$ (Fig. 6a). The $\mathrm{T}_{\mathrm{m}} \mathrm{CO}_{2}$ values in carbonic and aqueous-carbonic types, slightly below the triple point of pure $\mathrm{CO}_{2}$ $\left(-56.6{ }^{\circ} \mathrm{C}\right)$, indicate the dominance of $\mathrm{CO}_{2}$ and the presence of other gases in subordinate amounts. This is confirmed by Raman microprobe analysis, which identified only minor amounts of $\mathrm{CH}_{4}$ (1-4 mol\%) in the volatile phase. $\mathrm{N}_{2}$ and $\mathrm{H}_{2} \mathrm{~S}$ species have not been 
Table 2

Average composition of sulfide minerals from Llamas de Cabrera mine district (Py: pyrite, Gn: galena, Ttr: tetrahedrite, Sp: sphalerite, Po: pyrrhotite, Ccp: chalcopyrite, Cv: covellite).

\begin{tabular}{|c|c|c|c|c|c|c|c|c|}
\hline Mineral & Py & Py & $\mathrm{Gn}$ & Ttr-Fre & Sp & Po & Ccp & $\mathrm{CV}$ \\
\hline Stage & 1 & II & III & III & III & III & III & Superg. \\
\hline $\mathrm{N}$ & 15 & 21 & 9 & 4 & 15 & 3 & 5 & 3 \\
\hline Ag wt.\% & $<0.01$ & 0.01 & 0.01 & 24.33 & $<0.01$ & $<0.01$ & 0.12 & 0.91 \\
\hline Au & 0.02 & 0.02 & $<0.01$ & $<0.01$ & 0.31 & 0.09 & $<0.01$ & $<0.01$ \\
\hline $\mathrm{Bi}$ & 0.18 & 0.16 & 0.20 & 0.05 & 0.05 & 0.15 & 0.10 & 0.12 \\
\hline $\mathrm{Cd}$ & 0.01 & 0.01 & 0.12 & 1.44 & 1.29 & $<0.01$ & $<0.01$ & $<0.01$ \\
\hline $\mathrm{Cu}$ & $<0.02$ & $<0.02$ & $<0.02$ & 20.00 & $<0.02$ & 0.65 & 31.85 & 62.70 \\
\hline$S$ & 53.71 & 52.46 & 13.58 & 22.89 & 33.38 & 39.89 & 35.07 & 34.46 \\
\hline $\mathrm{Fe}$ & 45.61 & 45.73 & 0.01 & 3.79 & 7.39 & 57.91 & 31.03 & $<0.01$ \\
\hline As & 0.03 & 0.98 & $<0.02$ & $<0.02$ & $<0.02$ & $<0.02$ & $<0.02$ & $<0.02$ \\
\hline $\mathrm{Sb}$ & 0.05 & 0.04 & 0.26 & 27.20 & 0.05 & 0.04 & 0.04 & 0.09 \\
\hline $\mathrm{Pb}$ & 0.27 & 0.31 & 85.94 & 0.45 & 0.18 & 0.29 & 0.21 & 0.26 \\
\hline $\mathrm{Zn}$ & $<0.02$ & $<0.02$ & $<0.02$ & 0.18 & 57.41 & 1.05 & 1.13 & $<0.02$ \\
\hline Total & 99.88 & 99.72 & 100.12 & 100.33 & 100.06 & 100.07 & 99.56 & 98.54 \\
\hline Ag at.\% & 0.00 & 0.00 & 0.01 & 14.47 & 0.00 & 0.00 & 0.05 & 0.41 \\
\hline Au & 0.00 & 0.00 & 0.00 & 0.00 & 0.08 & 0.02 & 0.00 & 0.00 \\
\hline $\mathrm{Bi}$ & 0.04 & 0.03 & 0.11 & 0.01 & 0.01 & 0.03 & 0.02 & 0.03 \\
\hline $\mathrm{Cd}$ & 0.00 & 0.00 & 0.12 & 0.84 & 0.56 & 0.00 & 0.00 & 0.00 \\
\hline $\mathrm{Cu}$ & 0.00 & 0.00 & 0.00 & 20.08 & 0.00 & 0.44 & 23.08 & 47.58 \\
\hline$S$ & 67.12 & 66.19 & 50.21 & 45.63 & 50.37 & 53.82 & 50.36 & 51.84 \\
\hline $\mathrm{Fe}$ & 32.72 & 33.18 & 0.03 & 4.31 & 6.40 & 44.86 & 25.58 & 0.00 \\
\hline As & 0.02 & 0.53 & 0.00 & 0.00 & 0.00 & 0.00 & 0.00 & 0.00 \\
\hline $\mathrm{Sb}$ & 0.02 & 0.01 & 0.26 & 14.29 & 0.02 & 0.01 & 0.01 & 0.04 \\
\hline $\mathrm{Pb}$ & 0.05 & 0.06 & 49.17 & 0.14 & 0.04 & 0.06 & 0.05 & 0.06 \\
\hline $\mathrm{Zn}$ & 0.00 & 0.00 & 0.00 & 0.17 & 42.50 & 0.69 & 0.80 & 0.00 \\
\hline
\end{tabular}

detected. No aqueous-carbonic fluid inclusions have been found at Pozos deposit.

The first melting of ice in Type 3 inclusions was recognized near $-21{ }^{\circ} \mathrm{C}$, indicating the predominance of $\mathrm{NaCl}$ among dissolved salts. Type 3 are aqueous low salinity fluid inclusions displaying $\mathrm{T}_{\mathrm{m}}$ ice between -5.6 and $-1.4{ }^{\circ} \mathrm{C}$ that correspond to equivalent salinity of 2.4 to $8.6 \mathrm{wt} \% \mathrm{NaCl}$. Homogenization occurs to the liquid phase $\left(\mathrm{T}_{\mathrm{h}}\right)$ between 130 and $285^{\circ} \mathrm{C}$, but most of the highest values $\left(230-285^{\circ} \mathrm{C}\right.$ ) were registered at Pozos deposit (Fig. 6b). Densities

Table 3

Average composition of arsenopyrite analyses from Llamas de Cabrera mine district.

\begin{tabular}{|c|c|c|c|c|c|}
\hline \multirow{2}{*}{$\frac{\text { Mineral }}{\text { Stage }}$} & \multicolumn{5}{|c|}{ Arsenopyrite } \\
\hline & \multirow{2}{*}{$\frac{1}{\text { Tabuyo }}$} & \multirow{2}{*}{$\frac{1}{\text { Llamas }}$} & \multirow{2}{*}{$\frac{\text { II }}{\text { Llamas }}$} & \multirow{2}{*}{$\frac{\text { II }}{\text { Pozos }}$} & \multirow{2}{*}{$\frac{\text { II }}{\text { Pombriego }}$} \\
\hline Site & & & & & \\
\hline $\mathrm{N}$ & 2 & 19 & 32 & 17 & 11 \\
\hline Agwt.\% & $<0.01$ & 0.01 & 0.02 & 0.02 & $<0.01$ \\
\hline $\mathrm{Au}$ & 0.03 & $<0.01$ & 0.01 & 0.01 & 0.01 \\
\hline $\mathrm{Bi}$ & 0.04 & 0.10 & 0.06 & 0.06 & 0.09 \\
\hline Co & 0.06 & 0.03 & 0.04 & 0.18 & 0.32 \\
\hline $\mathrm{Fe}$ & 36.07 & 36.29 & 36.20 & 35.72 & 35.80 \\
\hline As & 42.56 & 42.13 & 40.99 & 41.02 & 41.43 \\
\hline 5 & 20.69 & 21.19 & 22.01 & 21.83 & 21.76 \\
\hline $\mathrm{Pb}$ & 0.11 & 0.12 & 0.12 & 0.12 & 0.14 \\
\hline $\mathrm{Ni}$ & $<0.01$ & 0.01 & $<0.01$ & 0.34 & 0.07 \\
\hline $\mathrm{Sb}$ & 0.07 & 0.15 & 0.10 & $<0.01$ & 0.06 \\
\hline Total & 99.63 & 100.06 & 99.65 & 99.45 & 99.71 \\
\hline Ag at.\% & 0.00 & 0.00 & 0.01 & 0.01 & 0.00 \\
\hline Au & 0.01 & 0.00 & 0.00 & 0.00 & 0.00 \\
\hline $\mathrm{Bi}$ & 0.01 & 0.03 & 0.02 & 0.02 & 0.02 \\
\hline $\mathrm{Co}$ & 0.05 & 0.03 & 0.03 & 0.16 & 0.29 \\
\hline $\mathrm{Fe}$ & 34.69 & 34.63 & 34.40 & 34.03 & 34.07 \\
\hline As & 30.51 & 29.97 & 29.04 & 29.14 & 29.39 \\
\hline 5 & 34.66 & 35.23 & 36.42 & 36.24 & 36.08 \\
\hline $\mathrm{Pb}$ & 0.03 & 0.03 & 0.03 & 0.03 & 0.04 \\
\hline $\mathrm{Ni}$ & 0.00 & 0.01 & 0.00 & 0.31 & 0.06 \\
\hline $\mathrm{Sb}$ & 0.03 & 0.07 & 0.04 & 0.00 & 0.02 \\
\hline
\end{tabular}

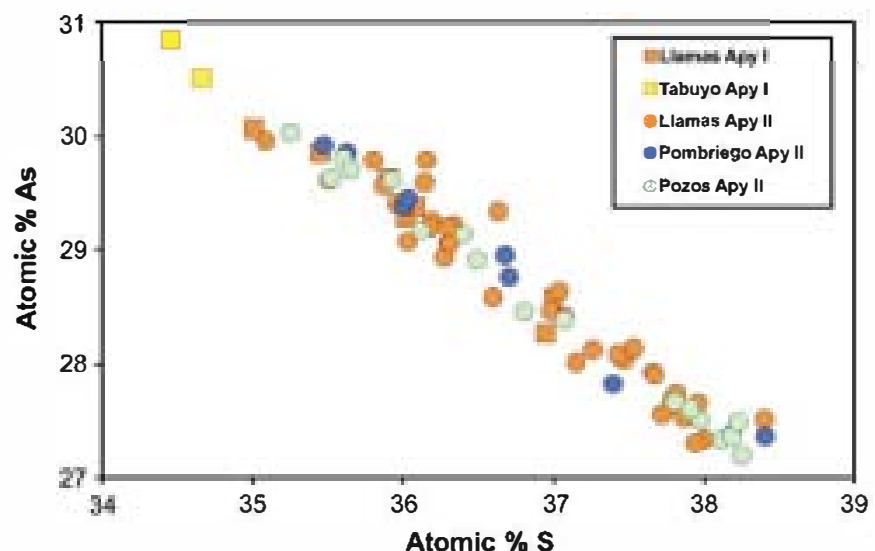

Fig. 5. The content of As and S (at.\%) in arsenopyrite (Apy).

range between 0.79 and $0.98 \mathrm{~g} / \mathrm{cm}^{3}$. No $\mathrm{C}-\mathrm{O}-(\mathrm{N}-\mathrm{S})$ species have been detected by Raman microprobe in Type 3 fluid inclusions.

\section{Stable isotope studies}

\subsection{Sulfides}

Results of sulfur isotope study show that $\delta^{34} S$ values for arsenopyrite, pyrite, and sphalerite are moderately heavy, ranging from +8.0 to $+23.1 \%$ with most of the values clustering between +9.0 and $+14.2 \%$. The determined range of ${ }^{34} \mathrm{~S}$ values does not seem to depend on the different analyzed sulfides, arsenopyrite, pyrite, and sphalerite, including arsenopyrite and pyrite from the first and second generation, and does not display significant differences between the deposits (Table 5; Fig. 7). Sulfur isotope analyses were also performed on four post- $S_{1}$ pyrites from slates of the Luarca Formation close to the quartz-gold veins. The $\delta^{34} \mathrm{~S}$ values of pyrites from slates range between +7.4 and $+26.3 \%$, similar to those of sulfides separated from ores.

\subsection{Quartz}

The $\delta^{18} \mathrm{O}$ values for both quartz generations $(\mathrm{Qz} \mathrm{I}$ and $\mathrm{Qz}$ II) from all the studied quartz-gold veins are similar and range from +9.3 to $+16.1 \%$. Qz I and Qz II show similar $\delta^{18} \mathrm{O}$ values, quartz I between +9.3 and $+15.9 \%$ and quartz II between +13.7 and 16\%. (Table 6 ; Fig. 8a) Assuming a formation temperature for the two quartz generations $\left(\mathrm{Qz}\right.$ I and $\mathrm{Qz}$ II) of between 330 and $290^{\circ} \mathrm{C}$, as deduced from microthermometry of aqueous-carbonic fluids, the calculated $\delta^{18} \mathrm{O}_{\text {fluid }}$ (using the equation of Zheng, 1993) varied from +3.2 to $+9.4 \%$, clustering from +6.7 to $+9.4 \%$ o (Table 6 ; Fig. 8 b). No suitable fluid inclusions for microthermometric study have been found in Pombriego and no aqueous-carbonic fluid inclusions have been recognized in Valdecorrales and Pozos veins. Therefore $\delta^{18} \mathrm{O}_{\text {fluid }}$ could not be calculated for Valdecorrales and Pozos samples, VDC-47 and PZ-2, PZ-3 respecively. Estimated temperature using the arsenopyrite composition has been used for $\delta^{18} \mathrm{O}_{\text {fluid }}$ calculation for quartz from Pombriego.

\section{Discussion and conclusion}

\subsection{Fluid evolution and ore-forming conditions}

The appearance of the three types of fluids in Llamas de Cabrera district could be interpreted as an example of continuous fluid evolution, where there was a significant change from $\mathrm{CO}_{2}$-bearing fluids to dominant aqueous fluids. The ore-forming fluids show an evolutionary trend from early high temperature aqueous-carbonic fluids with low density and salinity to low temperature aqueous fluids with high density and low to moderate salinity. The $\mathrm{T}_{\mathrm{m}}$-salinity plot 
Table 4

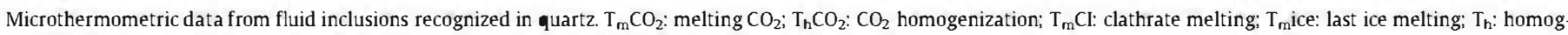
enization to vapor (V) or liquid (L); N: number of measurements. N.o: not observed.

\begin{tabular}{|c|c|c|c|c|c|c|c|c|c|c|c|}
\hline Components/fluid type & Deposit & Sample & $\mathrm{N}$ & Vapor $(\%)$ & $\mathrm{T}_{\mathrm{m}} \mathrm{CO}_{2}\left({ }^{\bullet} \mathrm{C}\right)$ & $\mathrm{T}_{\mathrm{h}} \mathrm{CO}_{2}\left({ }^{\bullet} \mathrm{C}\right)$ & $\mathrm{T}_{\mathrm{m}} \mathrm{Cl}\left({ }^{\circ} \mathrm{C}\right)$ & $\mathrm{T}_{\mathrm{m}}$ ice $\left({ }^{\circ} \mathrm{C}\right)$ & $\mathrm{T}_{\mathrm{h}}\left({ }^{\circ} \mathrm{C}\right)$ & $\begin{array}{l}\text { Density } \\
\left(\mathrm{gr} / \mathrm{cm}^{3}\right)\end{array}$ & $\begin{array}{l}\text { Salinity } \\
\text { (wt.\% } \mathrm{NaCl} \text { eq) }\end{array}$ \\
\hline $\begin{array}{c}\mathrm{CO}_{2}-\left(\mathrm{CH}_{4}\right) \\
\text { Type } 1\end{array}$ & Valdecorrales & VCD-47 (1) & 6 & $10-40$ & $-58.4 /-57.5$ & $4.4 / 12 \mathrm{~L}$ & $=$ & - & * & $0.85-0.90$ & $*$ \\
\hline $\mathrm{H}_{2} \mathrm{O}-\mathrm{NaCl}-\mathrm{CO}_{2}-\left(\mathrm{CH}_{4}\right)$ & Llamas de Cabrera A & LLA-14 & 7 & $20-40$ & $-57.8 /-57.1$ & $21.6 / 22.5 \mathrm{~V}$ & $8.3 / 9.1$ & n.o. & $320 / 332 \mathrm{~L}$ & $0.74-0.76$ & $2.0 / 3.4$ \\
\hline \multirow[t]{5}{*}{ Type 2} & Llamas de Cabrera B & LLB-4 & 6 & $8-25$ & $-57.6 /-57.1$ & $21.8 / 23.7 \mathrm{~L}$ & $7.8 / 8.9$ & n.o. & $306 / 312 \mathrm{~L}$ & $0.74-0.76$ & $2.2 / 4.1$ \\
\hline & Llamas de Cabrera C & LLC-10-11 & 6 & $10-30$ & $-58.4 /-57.6$ & $20.7 / 21.4 \mathrm{~L}$ & $8.7 / 9.3$ & n.o. & $307 / 316 \mathrm{~L}$ & $0.76-0.77$ & $1.4 / 2.8$ \\
\hline & & LLC-8 & 5 & $10-30$ & $-57.8 /-57.3$ & $22.7 / 25.2 \mathrm{~V}$ & $8.8 / 9.3$ & n.o. & $290 / 360 \mathrm{~L}$ & $0.71-0.74$ & $1.4 / 2.4$ \\
\hline & Villalibre & VL-1 & 8 & $30-40$ & $-57.3 /-56.7$ & $25.8 / 29.3 \mathrm{~L}$ & $7.9 / 8.7$ & n.o. & $285 / 319 \mathrm{~L}$ & $0.62-0.70$ & $2.6 / 4.1$ \\
\hline & Tabuyo & TA-40 & 5 & $20-30$ & $-57.3 /-57$ & $23.5 / 27.3 \mathrm{~L}$ & $8.3 / 9.0$ & n.o. & $285 / 295 \mathrm{~L}$ & $0.67-0.71$ & $2.0 / 2.4$ \\
\hline $\mathrm{H}_{2} \mathrm{O}-\mathrm{NaCl}$ & Valdecorrales & VDC-47 (1) & 6 & $10-20$ & - & - & - & $-2.1 /-1.4$ & $175 / 230 \mathrm{~L}$ & $0.89-0.93$ & $2.4 / 3.5$ \\
\hline \multirow[t]{7}{*}{ Type 3} & Llamas de Cabrera A & LLA-14 & 4 & $10-30$ & - & - & - & $-4 /-3.4$ & $185 / 192 \mathrm{~L}$ & $0.92-0.93$ & $5.5 / 6.4$ \\
\hline & Llamas de Cabrera B & LLB-4 & 5 & $10-20$ & - & - & - & $-2.8 /-3.2$ & $187 / 196 \mathrm{~L}$ & $0.91-0.92$ & $4.5 / 4.8$ \\
\hline & Llamas de Cabrera $C$ & LLC-1011 & 5 & $8-10$ & - & - & - & $-5.6 /-2.1$ & $138 / 211 \mathrm{~L}$ & $0.92-0.96$ & $3.4 / 8.6$ \\
\hline & & LLC-8 & 4 & $8-10$ & - & - & - & $-2 /-4$ & $135 / 138 \mathrm{~L}$ & $0.93-0.96$ & $3.3 / 6.4$ \\
\hline & Pozos & $P Z-5(4)$ & 9 & $8-20$ & - & - & - & $-4.5 /-2.9$ & $230 / 285 \mathrm{~L}$ & $0.83-0.92$ & $4.7 / 7.1$ \\
\hline & Villalibre & VL-1 & 4 & $10-15$ & - & - & - & $-2.3 /-1.6$ & $132 / 140 \mathrm{~L}$ & $0.84-0.95$ & $2.7 / 3.9$ \\
\hline & Tabuyo & $\mathrm{TA}-40(1)$ & 6 & $5-20$ & - & - & - & $-4.7 /-1.8$ & $138 / 276 \mathrm{~L}$ & $0.82-0.95$ & $2.9 / 7.4$ \\
\hline
\end{tabular}

a

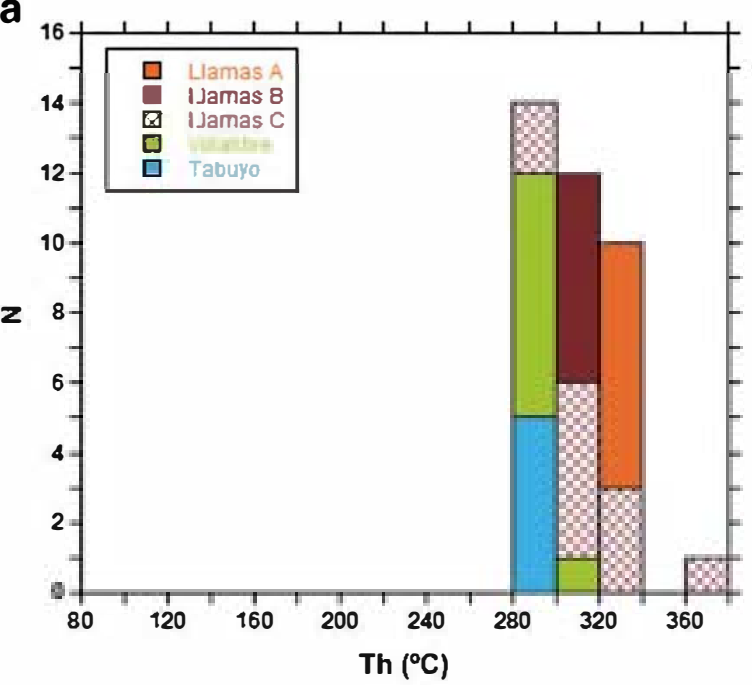

b

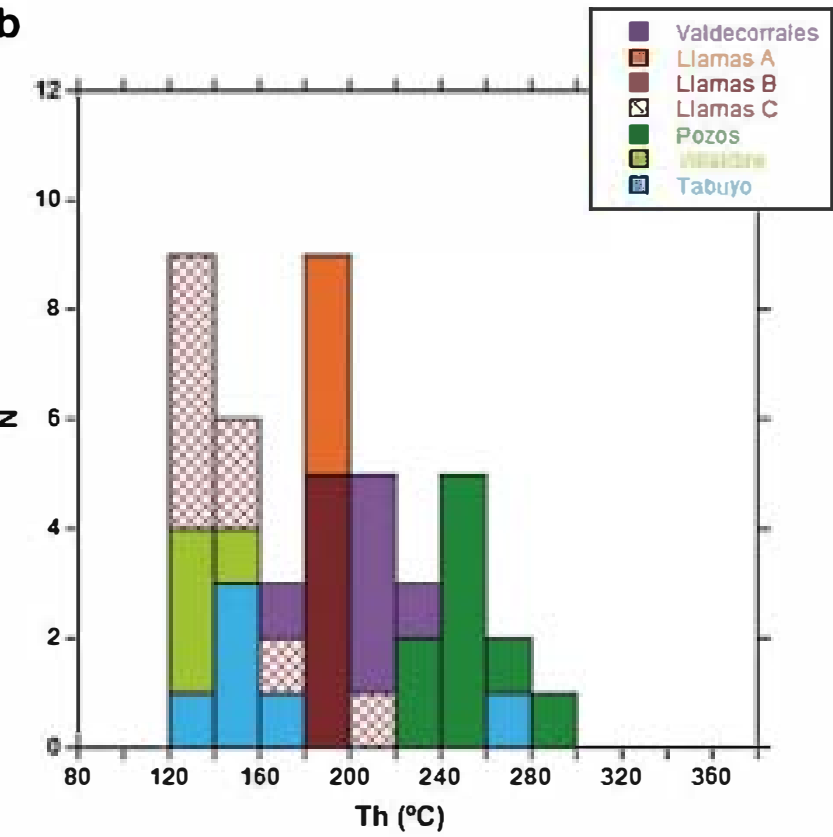

Fig. 6. Histograms of homogenization temperature: (a) aqueous-carbonic fluid inclusions (b) aqueous inclusions.
(Fig. 9) shows the general fluid evolution, indicating a clear increase in fluid salinity with a decrease in $\mathrm{T}_{\mathrm{h}}$. The $\mathrm{H}_{2} \mathrm{O}-\mathrm{NaCl}-\mathrm{CO}_{2}-\left(\mathrm{CH}_{4}\right)$ fluid could be interpreted as an early fluid coexisting with the formation of quartz that displays a low salinity range $(1.4-4.1 \mathrm{wt} . \% \mathrm{NaCl}$ equiv.) in a relatively high $\mathrm{T}_{h}$ range $\left(285-360^{\circ} \mathrm{C}\right)$. The late $\mathrm{H}_{2} \mathrm{O}-$ $\mathrm{NaCl}$ fluid displays low to moderate salinity $(2.4$ to $8.6 \mathrm{wt} . \% \mathrm{NaCl}$ equiv.) and lower homogenization temperature $\left(130-210^{\circ} \mathrm{C}\right)$. Fluids at Pozos deposit exhibit a peculiar evolution with dominantly $\mathrm{H}_{2} \mathrm{O}-$ $\mathrm{NaCl}$ composition, showing higher homogenization temperatures $\left(230-285^{\circ} \mathrm{C}\right)$ compared to other mineralizations in the region and moderate salinities (4.7-7.1 wt.\% $\mathrm{NaCl}$ equiv.).

The $\mathrm{CO}_{2}-\left(\mathrm{CH}_{4}\right)$ fluid inclusions with no visible water have not been observed before in the gold-quartz veins from the northwest of the Iberian Peninsula. Previous studies of gold mineralizations from this area (Boiron et al., 1996; Couto et al., 1990; Noronha et al., 2000; Tornos et al., 1997) or central Iberia (Murphy and Roberts, 1997) recognized only aqueous-carbonic fluids. $\mathrm{CO}_{2}$-rich fluid inclusions are ubiquitous in vein-quartz gold deposits hosted in metamorphic terranes as a subordinate population in close association with cogenetic aqueous-carbonic fluids (Klein et al., 2006). Several models

Table 5

Sulfur isotope data for sulfide minerals from main deposits of Llamas de Cabrera district.

\begin{tabular}{|c|c|c|c|c|}
\hline District & Vein location & Sample & Mineral & $\begin{array}{l}\delta^{34} \mathrm{~S} \\
(\% \mathrm{~V}-\mathrm{CDT})\end{array}$ \\
\hline \multirow[t]{3}{*}{ Pombriego } & & PMB-31 & Arsenopyrite I & 12.7 \\
\hline & & PMB-31 & Pyrite I & 14.2 \\
\hline & & PMB-31 & Pyrite I & 13.9 \\
\hline Valdecorrales & & VDC-47 & Arsenopyrite I & 8.0 \\
\hline \multirow[t]{9}{*}{ Llamas de Cabrera } & Zone A & LlA-1 & Arsenopyrite II & 11.1 \\
\hline & & LlA-1 & Arsenopyrite II & 12.3 \\
\hline & $\begin{array}{l}\text { Zone B } \\
\text { (El Zanjón) }\end{array}$ & LLB-5 & Arsenopyrite I & 9.7 \\
\hline & Zone $\mathrm{C}$ & LLC-131 & Arsenopyrite I & 13.0 \\
\hline & & LLC-3Q & Arsenopyrite I & 9.7 \\
\hline & & LLC-3C & Arsenopyrite I & 10.2 \\
\hline & & LLC-33 & Pyrite II & 11.2 \\
\hline & & LLC-33 & Arsenopyrite II & 9.0 \\
\hline & & LLC-8 & Arsenopyrite II & 9.5 \\
\hline Villalibre & & VL-1 & Arsenopyrite II & 23.1 \\
\hline \multirow[t]{3}{*}{ Pozos } & & PZ-2 & Pyrite II & 19.5 \\
\hline & & $\mathrm{PZ}-4$ & Arsenopyrite II & 13.0 \\
\hline & & PZ-5 & Sphalerite & 11.0 \\
\hline Tabuyo & & $\mathrm{TA}-40$ & Arsenopyrite I & 16.3 \\
\hline Post-kinematic pyrite & & ALB-43S & Pyrite & 26.3 \\
\hline \multirow[t]{3}{*}{ "Luarca slate" } & & ALB-44S & Pyrite & 7.4 \\
\hline & & PMB-29S & Pyrite & 20.4 \\
\hline & & MAN-36S & Pyrite & 16.2 \\
\hline
\end{tabular}




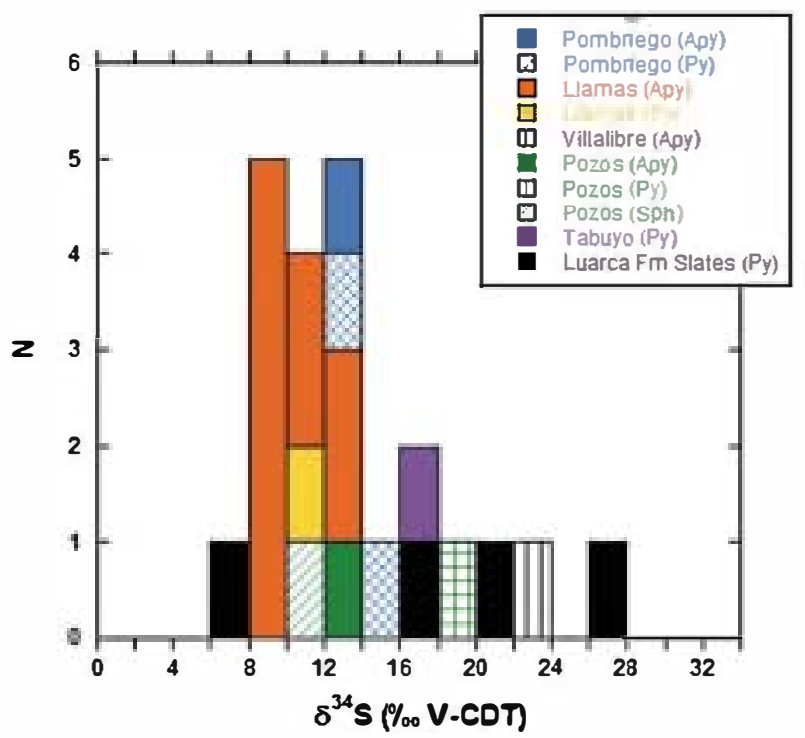

Fig. 7. Histogram of $8^{34} \mathrm{~S}$ for arsenopyrite, pyrite and sphalerite from main deposits of Llamas de Cabrera district.

have explained the origin of carbonic fluid inclusions in gold deposits (Chi et al., 2009; Garba and Akande, 1992; Wille and Klemd, 2004).

The absence of significant $\mathrm{H}_{2} \mathrm{O}$ contents in these fluid inclusions contrasts with the formation of hydrous alteration minerals such as sericite and chlorite close to the veins. The $\mathrm{CO}_{2}-\left(\mathrm{CH}_{4}\right)$ fluid inclusions might be product of: (1) unmixing of a $\mathrm{H}_{2} \mathrm{O}-\mathrm{CO}_{2}$ fluid before trapping of the inclusions; and/or (2) re-equilibration of early fluids during $\mathrm{P}-\mathrm{T}$-change or deformation during or after trapping. Unmixing could be a valid hypothesis if it occurs before trapping and outside the depositional site

Table 6

Oxygen isotope data for quartz. $8^{\mathbf{1 8}} \mathrm{O}_{\text {fluid }}$ correspond to the isotopic composition of water in equilibrium with quartz. Quartz calculations were performed for temperature from 285 to $330^{\circ} \mathrm{C}$ and from using the fractionation equation of Zheng (1993).

\begin{tabular}{|c|c|c|c|c|c|c|}
\hline District & $\begin{array}{l}\text { Vein } \\
\text { location }\end{array}$ & Sample & Mineral & $\begin{array}{l}\mathbf{8}^{\mathbf{1 2}} \mathrm{O} \\
(\% \cdot \mathrm{SMOW})\end{array}$ & $\begin{array}{l}T_{h} \\
\left({ }^{\bullet} \mathrm{C}\right)\end{array}$ & $\begin{array}{l}\delta^{12} \mathrm{O}_{\text {fluid }} \\
(\% \text { SMOW })\end{array}$ \\
\hline \multirow[t]{2}{*}{ Pombriego } & & PMB-31 & Quartz II & 13.7 & 325 & 7.4 \\
\hline & & PMB-31 & Quartz II & 14.7 & 325 & 8.4 \\
\hline \multirow[t]{2}{*}{ Valdecorrales } & & VDC -47 & Quartz I & 14.3 & $\begin{array}{l}\text { No } \\
\text { data }\end{array}$ & \\
\hline & & VDC -47 & Quartz I & 14.4 & $\begin{array}{l}\text { No } \\
\text { data }\end{array}$ & \\
\hline \multirow{18}{*}{$\begin{array}{r}\text { Llamas de } \\
\text { Cabrera }\end{array}$} & A Zone & LIA-1 & Quartz I & 9.3 & 330 & 3.2 \\
\hline & & LIA-1 & Quartz I & 14.5 & 330 & 8.4 \\
\hline & & LIA-1 & Quartz II & 14.3 & 330 & 8.2 \\
\hline & B Zone & LLB-1 & Quartz I & 14.6 & 300 & 7.6 \\
\hline & (El Zanjón) & LLB-10 & Quartz I & 14.9 & 300 & 7.9 \\
\hline & & LLB-5 & Quartz II & 14.0 & 300 & 7.0 \\
\hline & & LLB-5 & Quartz II & 13.7 & 300 & 6.7 \\
\hline & C Zone & LLC-19 & Quartz I & 14.9 & 310 & 8.2 \\
\hline & & LLC-2 & Quartz I & 15.1 & 310 & 8.4 \\
\hline & & LLC-131 & Quartz I & 12.4 & 310 & 5.7 \\
\hline & & LLC-131 & Quartz II & 16.1 & 310 & 9.4 \\
\hline & & LLC-1011 & Quartz I & 14.1 & 310 & 7.4 \\
\hline & & LLC-33 & Quartz II & 15.2 & 310 & 8.5 \\
\hline & & LLC-11 & Quartz II & 14.0 & 310 & 7.3 \\
\hline & & LLC-11 & Quartz II & 14.5 & 310 & 7.8 \\
\hline & & LLC-3Q & Quartz I & 14,4 & 310 & 7.7 \\
\hline & & LLC-3Q & Quartz I & 14.9 & 310 & 8.2 \\
\hline & & LLC-8 & Quartz I & 14.7 & 310 & 8.0 \\
\hline Villalibre & & VL-1 & Quartz I & 14.9 & 285 & 7.4 \\
\hline \multirow[t]{2}{*}{ Pozos } & & PZ-2 & Quartz I & 15.1 & $\begin{array}{l}\text { No } \\
\text { data }\end{array}$ & \\
\hline & & PZ-4 & Quartz I & 15.9 & $\begin{array}{l}\text { No } \\
\text { data }\end{array}$ & \\
\hline \multirow[t]{2}{*}{ Tabuyo } & & TA-40 & Quartz I & 13.8 & 290 & 6.4 \\
\hline & & TA-40 & Quartz I & 13.8 & 290 & 6.4 \\
\hline
\end{tabular}
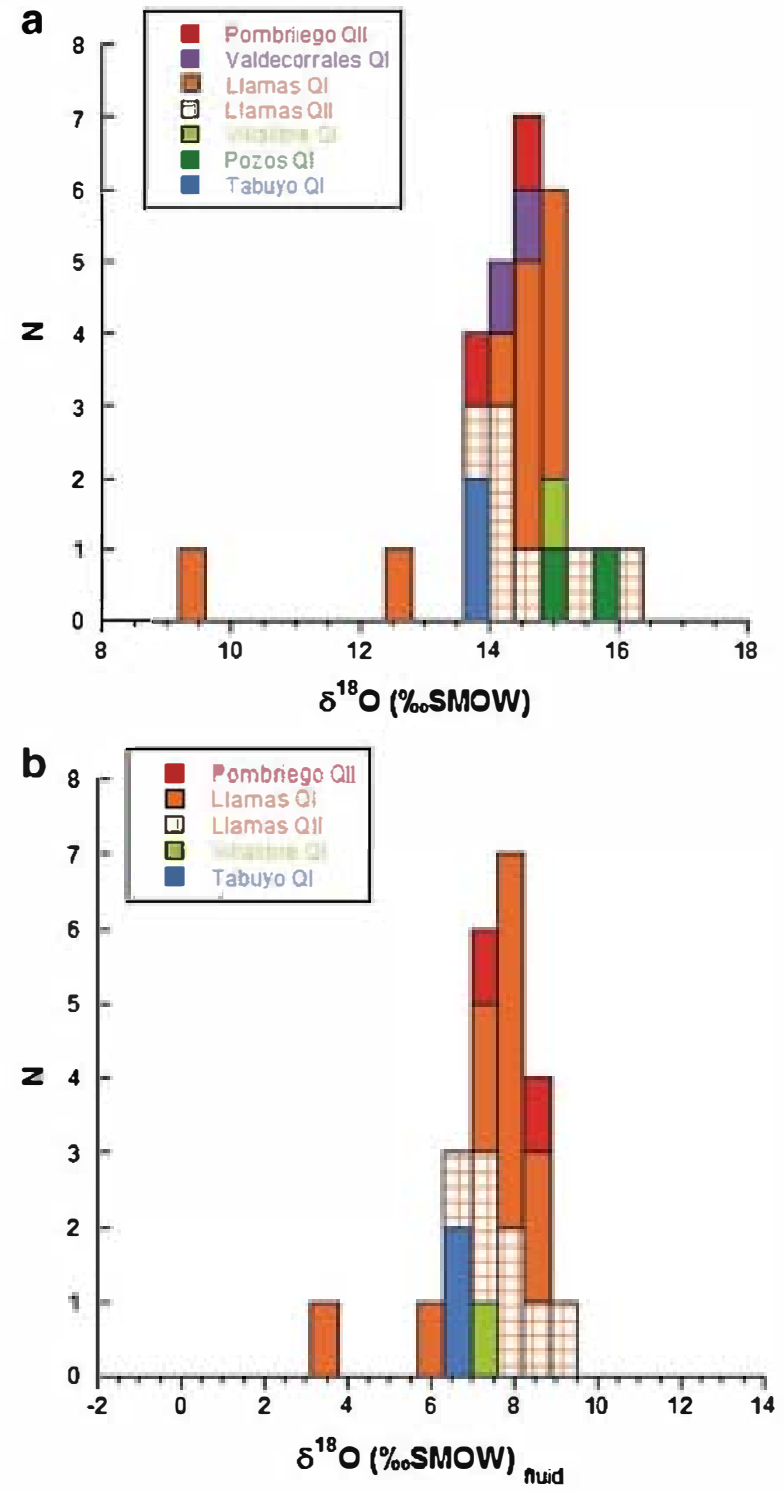

Fig. 8. a) Histogram of $6^{18} \mathrm{O}$ values for quartz b) Calculated $\boldsymbol{6}^{\mathbf{1 8}} \mathrm{O}$ fluid histogram.

(Chi et al., 2009, Klein and Fuzikawa, 2010). In this case the density and wetting contrast between $\mathrm{CO}_{2}$ and $\mathrm{H}_{2} \mathrm{O}$ favor trapping $\mathrm{CO}_{2}$-rich inclusions and the removal of the aqueous phase could contribute to the formation of hydrous alteration minerals in the vein-host rock contact. However, the presence of aqueous fluid inclusions along grain boundaries (Johnson and Hollister, 1995) and low trapping pressures would be expected. Trapping of fluid under low pressure is not consistent with the geological environment described for these deposits. Moreover, deformation could induce leakage of $\mathrm{H}_{2} \mathrm{O}$ from aqueous-carbonic fluid inclusions in quartz (Bakker and Jansen, 1991; Hollister, 1990, Huizenga and Touret, 1999; Klein et al., 2006). Based on the presence of milky quartz crystals (Qzl) with undulose extinction and serrate grain boundaries, the absence of water in the $\mathrm{CO}_{2}-\left(\mathrm{CH}_{4}\right)$ fluid inclusions could be interpreted by an eff ect of local re-equilibration provoked by deformation of the host quartz under fluctuating pressure conditions and deformation. However, $\mathrm{CO}_{2}-\left(\mathrm{CH}_{4}\right)$ fluid inclusions show relatively high densities in a close range $\left(0.85-0.9 \mathrm{~g} / \mathrm{cm}^{3}\right)$ and $\mathrm{H}_{2} \mathrm{O}$ leakage would lead to a variable density decrease in the remaining fluid. Unfortunately $\mathrm{CO}_{2}-\left(\mathrm{CH}_{4}\right)$ fluid inclusions are scarce and accordingly their origin remains uncertain.

Early aqueous-carbonic fluid inclusions were trapped in Qzl and QzlI quartz and are related to arsenopyrite and pyrite deposition. A drop in 


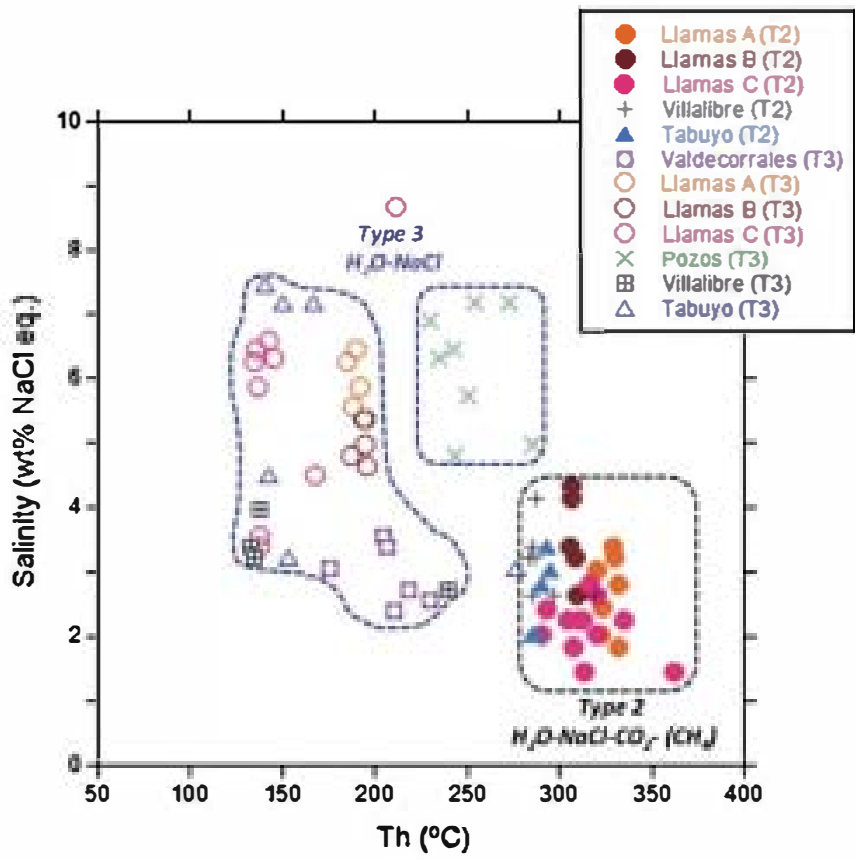

Fig. 9. Homogenization temperature versus salinity plot for $\mathrm{H}_{2} \mathrm{O}-\mathrm{NaCl}-\mathrm{CO}_{2}-\mathrm{CH}_{4}$ (type 2) and $\mathrm{H}_{2} \mathrm{O}-\mathrm{NaCl}$ fluids (type 3 ) in quartz.

temperature, decompression, and later stages of fracturing favored the infiltration of aqueous fluids which have been recognized along fluid inclusion planes. Aqueous fluids associated with gold paragenesis have low to moderate salinity ( 2.4 to $8.6 \mathrm{wt} \% \mathrm{NaCl}$ equiv.) and minimal trapping temperatures ranging from 130 to $285^{\circ} \mathrm{C}$. The $\mathrm{T}_{\mathrm{h}}$ range is too large to be simply the result of a pressure change, indicating a mixing process between two end-members during cooling. The first one had a moderate salinity, up to $9 \mathrm{wt} . \% \mathrm{NaCl}$ equiv., and the second one less than 2 wt.\% NaCl. Fluid inclusions recognized in Pozos deposit could represent the relatively saline hot aqueous fluid (Fig. 9). A mixing process is consistent with the findings for comparable As-Au mineralizations elsewhere in the Variscan belt of western Europe (Boiron et al., 2003). In conjunction with arsenopyrite geothermometry and fluid inclusion data, an attempt was made to determine the ore-forming conditions. Because of its refractory nature, arsenopyrite does not reequilibrate on rapid cooling and equilibrium compositions are usually preserved in hydrothermal deposits reflecting formation temperature (Choi and Youm, 2000). The arsenopyrite geothermometer for ore deposits formed at temperatures higher than $300^{\circ} \mathrm{C}$ was proposed by Kretschmar and Scott (1976) and re-examined by Sharp et al. (1985). The average composition of arsenopyrite I in pyrite I assemblages clusters at 30.51-30.95 at.\%As in Tabuyo deposit and at 28.37-30.07 at.\% As in llamas, corresponding to temperatures of $385 \pm 10^{\circ} \mathrm{C}$ and $330 \pm$ $10^{\circ} \mathrm{C}$ respectively. The average composition of arsenopyrite II in associaton with pyrite II exhibits a narrow variation, from 28.06 to 30.07 at.\% As in Llamas, 28.47 to 30.03 at.\% As in Pozos, and 28.76 to 29.93 at.\% As in Pombriego. Temperatures estimated from these data are $320 \pm 20^{\circ} \mathrm{C}$, $325 \pm 20^{\circ} \mathrm{C}$, and $325 \pm 15^{\circ} \mathrm{C}$ (Table 7). Decreasing As contents of arsenopyrite indicate a decrease in sulfur fugacity or/and temperature during stage II. No differences in As values are detected between the different deposits during stage II. The arsenopyrite geothermometry provides temperatures slightly above homogenization temperatures of aqueous-carbonic fluid inclusions $\left(285-330^{\circ} \mathrm{C}\right.$ with one outlier at $360^{\circ} \mathrm{C}$ ).

In a temperature range of $250-400^{\circ} \mathrm{C}$ substantial amounts of gold may be transported in chemical conditions where bisulphide complex predominates. The decrease in gold solubility below $200-250{ }^{\circ} \mathrm{C}$ together with a pressure drop, cooling, $\mathrm{pH}$ change, $\mathrm{H}_{2} \mathrm{~S}$ loss (sulphidation of iron-bearing minerals in the wall rocks), and oxidation appear to be effective mechanisms for gold precipitation (Gibert et al., 1998). In the context of Llamas de Cabrera district, dilution and mixing of two aqueous fluids of relatively contrasted salinity and temperature were favorable factors for decreasing gold solubility and could allow gold deposition. This model of gold deposition is similar to that observed in similar deposits in the Variscan belt (Boiron et al., 2003; Vallance et al., 2003).

A reconstruction of the pressure change during the ore stages has been carried out based on fluid inclusion isochores for each fluid circulation stage (Fig. 10). Extreme isochores give an estimate of the minimum pressure of trapping at a given temperature, and by considering other temperature and pressure indicators it was possible to place some constraints on the P-T conditions. Under brittle condition of deformation quartz veins are formed and aqueous-carbonic fluids observed in quartz contemporary with arsenopyrite and pyrite, probably records lithostatic pressures after the sealing of the fracture system. The minimal trapping temperatures $\left(T_{h}\right)$ of these fluids vary between 285 and $360{ }^{\circ} \mathrm{C}$ and correspond to minimal trapping pressures $\left(P_{h}\right)$ in the 190-240 MPa range. Constraints for the real trapping temperature and pressure are the following: (i) arsenopyrite geothermometry gives temperatures between 300 and $390{ }^{\circ} \mathrm{C}$ and (ii) peak of the regional metamorphism lower than 200-220 MPa (Díez Montes, 2007). As $\mathrm{CO}_{2}-\left(\mathrm{CH}_{4}\right)$ fluid inclusions could be interpreted by an effect of local re-equilibration their high density could not be representative of their trapping conditions (Vityk and Bodnar, 1995).

The latest fluids, which are associated with gold and $\mathrm{Zn}-\mathrm{Cu}-\mathrm{Pb}$ sulfides deposition are aqueous and were trapped at lower temperatures (minimum trapping temperatures in the range of $130-285^{\circ} \mathrm{C}$ ). Conditions of trapping are difficult to constrain due to the lack of mineralogical or other indicators at this stage, however they were probably trapped at pressures ( $\leq 200 \mathrm{MPa}$ ) similar or lower than those of the preceding stage (similar depth). These pressures indicate trapping temperatures ranging between 180 and $310^{\circ} \mathrm{C}$. A decrease in temperature, dilution and mixing of moderate to low salinity aqueous fluids could be related to gold deposition.

\subsection{Source of ore-forming materials and fluids}

The average value of $8^{34} S$ of minerals can represent that of the total sulfur in the hydrothermal fluid when the mineral association is simple (Ohmoto and Rye, 1979). The relatively tight clustering of the $\delta^{34} \mathrm{~S}(+9.0$ to $+14.2 \%)$ in sulfides from quartz-gold veins can be interpreted to indicate that the fluid redox state was below the $\mathrm{SO}_{2} / \mathrm{H}_{2} \mathrm{~S}$ boundary and $\mathrm{H}_{2} \mathrm{~S}$ was the dominant reduced sulfur species in the fluids (Ohmoto and Rye, 1979). In $\mathrm{H}_{2} \mathrm{~S}$ predominant fluid, sulfide minerals precipitated from solution would exhibit $\delta^{34} S$ values similar to the $\delta^{34} \mathrm{~S} \sum s$ value of the fluids. The similar sulfur isotope composition of stage I sulfides (from $+8.0 \%$ to $+16.3 \%$, Table 5) to that of stage II sulfides $(+9.0 \%$ o to $+19.5 \%$, with one outlier at $+23.1 \%$ ) suggests that both mineral stages share an identical or directly comparable sulfur source.

As shown in Fig. 7, the $\delta^{34} \mathrm{~S}$ values of sulfides separated from quartz-gold veins are similar to those of post- $S_{1}$ pyrites from siliciclastic Luarca Formation exhibiting $\delta^{34} \mathrm{~S}$ values between +7.4 and $+20.4 \%$ ( with the highest value at $+26.3 \%$ ). This feature may reflect that country rocks of quartz-gold veins have provided sulfur to the fluid system. The hydrothermal transport would tend to homogenize the $\delta^{34} \mathrm{~S}$, so that ores would display more constant values than the sources.

Similar $\delta^{34} S$ values $(+6.7$ to $+18.0 \%$ ) were reported by Tornos et al. (1997) in gold deposits from Teleno area and by Arias et al. (1997) in the gold Navia Belt $(+9.7$ to $+20.6 \%$ ), both hosted by Cambrian-Ordovician rocks in West Asturian Leonese Zone.

Quartz (Qz I and Qz II) crystallized from a $\mathrm{CO}_{2}$-bearing fluid with a ${ }^{18} \mathrm{O}_{\text {fluid }}$ component clustering from +6.4 to $9.4 \%$ (Fig. 8). These 


\begin{tabular}{|c|c|c|c|c|c|c|c|}
\hline \multirow[b]{2}{*}{ Mine site } & \multirow[b]{2}{*}{ Sample } & \multicolumn{4}{|l|}{ At.\% As } & \multirow{2}{*}{$\begin{array}{l}\text { Estimated temperature } \\
\left({ }^{\bullet} \mathrm{C}\right)\end{array}$} & \multirow{2}{*}{$\begin{array}{l}\text { Apy } \\
\text { type }\end{array}$} \\
\hline & & Average & S.D. ${ }^{a}$ & Range & $\mathrm{N}^{\mathrm{b}}$ & & \\
\hline Tabuyo & TA-40 & 30.73 & 0.31 & $30.51-30.95$ & 2 & $385 \pm 10$ & I \\
\hline Llamas & LLC-132B & 29.47 & 0.53 & $28.57-30.07$ & 8 & $330 \pm 10$ & I \\
\hline Llamas & LLC-8 & 29.07 & 0.76 & $28.59-29.42$ & 11 & $315 \pm 15$ & II \\
\hline Llamas & LLC-132 & 29.21 & 0.85 & $28.42-29.80$ & 21 & $320 \pm 20$ & II \\
\hline Llamas & VDC-47(2) & 29.19 & 0.81 & $28.06-29.96$ & 9 & $320 \pm 20$ & II \\
\hline Pozos & $P Z-5(3)$ & 29.20 & 0.76 & $28.47-30.03$ & 20 & $325 \pm 20$ & II \\
\hline Pombriego & PMB-31E & 29.12 & 0.47 & $28.76-29.93$ & 6 & $325 \pm 15$ & II \\
\hline
\end{tabular}

a Standard deviation.

b Number of spot analyses by electron microprobe.

values lie within the range for a metamorphic source (Sheppard, 1986) and are characteristic of fluids isotopically in equilibrium with common basement materials at medium to high temperatures $\left(285-330^{\circ} \mathrm{C}\right)$. Taking the absence of igneous rocks in the llamas de Cabrera area into account, calculated $\delta^{18} \mathrm{O}_{\text {fluid }}$ values suggest that aqueous-carbonic fluids correspond to metamorphic (dehydrationdecarbonation during prograde metamorphism) or aqueous fluids of unknown origin largely equilibrated with metamorphic lithologies between 300 and $400{ }^{\circ} \mathrm{C}$.

The high temperature implies high heat flows which have been related in other gold deposits of the northwest of the Iberian Peninsula to the presence of granites (Boiron et al., 2003; Noronha et al., 2000; Vallance et al., 2003). In the case of Llamas de Cabrera the lack of igneous rocks exposed in the area requires some interpretation to explain the source of heat. Actually, there are several types of igneous rocks underlying the mineralized area (cross section, Fig. 1b) but most of them present characteristics which preclude a possible genetic relation to the gold ore. The volcanic related Ollo de Sapo Formation magmatism has been dated 472 to $488 \mathrm{Ma}$ (U-Pb on zircon) by Diez Montes (2007); this means they are Upper Cambrian to Lower Ordovician in age and clearly pre-Variscan. Another group of intrusive bodies were classified as early syn-kinematic and syn-kinematic epi- and mesozonal granitoides; all of them underwent Variscan deformation and regional metamorphism with a peak and partial melting during D2. This metamorphism (M2/D2) was dated in the Ollo de Sapo antiform at 314 to $311 \mathrm{Ma}$ by the U-Pb method on monazite. The peak $\mathrm{P}$ and $\mathrm{T}$ conditions $\left(480-520^{\circ} \mathrm{C}, 450-500 \mathrm{MPa}\right)$ recorded in the Ordovician metasediments (Díez Montes, 2007) were much higher than those suggest here for the Llamas de Cabrera

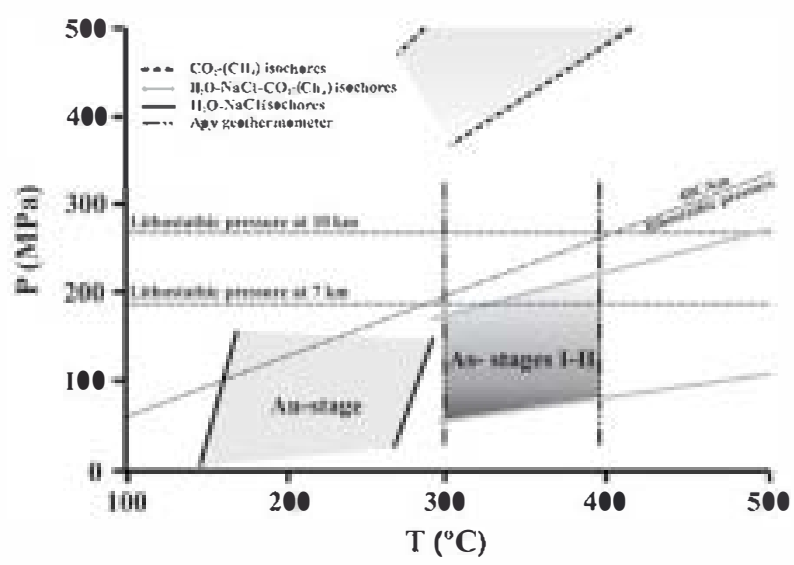

Fig. 10. Pressure-temperature reconstruction of conditions prevailing in Llamas de Cabrera deposit; data from mineral geothermometer and probable trapping conditions of the different of fluid inclusions.
Au mineralization. Thus, Au mineralization must have occurred later than M2. The only other magmatism known in the region is the Variscan post-kinematic Veiga granodiorite and other minor similar bodies placed to the east (Diez Montes, 2007). The Veiga granodiorite was dated by Ortega Cuesta et al. (2000a, 2000b) at $286 \pm 6$ Ma using the $\mathrm{Rb} / \mathrm{Sr}$ method on whole rocks. These authors suggest that it is a post-kinematic epizonal body intruded during the extensional collapse which followed the Variscan crustal thickening. Furthermore, the estimated $\mathrm{P}$ and $\mathrm{T}$ grade at the Truchas Syncline during the lateVariscan extensional events is strongly consistent with the conditions presented here for the Llamas de Cabrera gold mineralization. Therefore, the ascent of some late Variscan (post-kinematic) magmatic bodies, not exposed at the present day erosion level, could act as a strong heat engine and remobilize gold from the metamorphic rocks. The age of this event (around $290 \mathrm{Ma}$ ) is younger than the metalliferous peak (310-300 Ma) established in the French Massif Central (Bouchot et al., 2005).

The deposition of gold is controlled by successive stages from high temperature aqueous-carbonic to low temperature aqueous fluid flowing along extension faults, breccias, and stockworks at the end of the Variscan orogeny. The aqueous-carbonic fluids result from a strong interaction with metamorphic rocks and characterized an early ore-stage with quartz, arsenopyrite, and minor pyrite deposition. An intense microfissuring of quartz and previous sulfides favored the circulation of aqueous fluids, and the mixing of aqueous fluids leads to gold and $\mathrm{Zn}-\mathrm{Cu}-\mathrm{Pb}$ sulfides precipitation. The ore fluids were mobilized during the Variscan doming generated for the syn-orogenic extensional processes and the related decompressive melting events.

\section{Comparison with other gold Variscan deposits in western Europe}

Gold-quartz veins from llamas de Cabrera display similar features and processes to related deposits of similar type elsewhere in the Variscan belt of western Europe, northwest and central/western Iberia, the French Massif Central, and the Bohemian Massif (Table 8). The paragenesis reveals an early As-Fe stage and a consequent $\mathrm{Pb}-\mathrm{Zn}-$ $\mathrm{Cu}-(\mathrm{Ag})$ stage, with Sb-rich mineral phases in some deposits. Native gold is associated with the second stage in most districts. Ubiquitous arsenopyrite generally has low gold concentration within its lattice. The presence of early aqueous-carbonic fluids that are associated with the As-Fe stage and that equilibrated with metamorphic rocks is a common feature for this mineralization type. The latest hydrothermal stage is characterized by the circulation of cooler aqueous fluids and by the mixing of moderately saline with dilute fluids of lower temperature. The $\delta^{18} \mathrm{O}_{\text {fluid }}$ data obtained in northwest Portugal, Massif Central, and other gold districts in northwest Spain show similar values, characteristic of fluids isotopically in equilibrium with common basement materials, magmatic, or metamorphic rocks. 
Table 8

Characteristics of the main Variscan gold vein deposit in Europe.

\begin{tabular}{|c|c|c|c|c|c|c|c|c|}
\hline \multirow{2}{*}{$\begin{array}{l}\text { Gold vein } \\
\text { district }\end{array}$} & \multirow[t]{2}{*}{ Orebody morphology and host rock } & \multirow[t]{2}{*}{ Paragenesis } & \multirow{2}{*}{$\begin{array}{l}\text { Fluid composition } \\
\text { and P-T conditions }\end{array}$} & \multicolumn{2}{|c|}{ Isotopic composition } & \multirow[t]{2}{*}{ Other characteristics } & \multirow{2}{*}{$\begin{array}{l}\text { Age } \\
\text { (Ma.) }\end{array}$} & \multirow[t]{2}{*}{ References. } \\
\hline & & & & $\begin{array}{l}8^{18} \mathrm{O}_{\text {nuid }} \\
(\% \text { SMOW })\end{array}$ & $\begin{array}{l}8^{34} \mathrm{~S} \\
(\% \cdot \mathrm{V}-\mathrm{CDT})\end{array}$ & & & \\
\hline $\begin{array}{l}\text { Northwest } \\
\text { Spain }\end{array}$ & $\begin{array}{l}\text { Quartz-arsenopyrite gold veins in granites } \\
\text { and Lower Cambrian to Middle Ordovician } \\
\text { metasediments }\end{array}$ & $\begin{array}{l}\text { Arsenopyrite-Pyrite-Gold } \pm \\
\text { sulfides }\end{array}$ & $\begin{array}{l}\mathrm{CO}_{2}-\left(\mathrm{CH}_{4}\right) \\
\mathrm{H}_{2} \mathrm{O}-\mathrm{NaCl}-\mathrm{CO}_{2}-\left(\mathrm{CH}_{4}\right) \\
\text { P-T: } 200-220 \mathrm{MPa}, \\
300-3900^{\circ} \mathrm{C} \\
\mathrm{H} 2 \mathrm{O}-\mathrm{NaCl} \\
\mathrm{P}-\mathrm{T}: \leq 200 \mathrm{MPa} \\
180-310^{\circ} \mathrm{C}\end{array}$ & $+3.2 /+9.4$ & $+6.7 /+18.0$ & $\begin{array}{l}\text { Stable isotope and fluid composition } \\
\text { indicate fluids equilibrated with host } \\
\text { rocks }\end{array}$ & & $\begin{array}{l}\text { This study } \\
\text { Arias et al. (1997) } \\
\text { Boiron et al. (1996) } \\
\text { Tornos et al.(1997) }\end{array}$ \\
\hline \multirow[t]{2}{*}{$\begin{array}{r}\text { Northwest } \\
\text { Portugal }\end{array}$} & $\begin{array}{l}\text { Quartz-arsenopyrite gold veins in granites } \\
\text { and Cambrian to Middle Ordovician } \\
\text { metasedimentay rocks. }\end{array}$ & $\begin{array}{l}\text { Arsenopyrite-Pyrite-Gold } \pm \\
\text { sulfides }\end{array}$ & $\begin{array}{l}\mathrm{H}_{2} \mathrm{O}-\mathrm{NaCl}-\mathrm{CO}_{2}-\mathrm{CH}_{4} \\
\mathrm{P}-\mathrm{T}: 100-300 \mathrm{MPa}, \\
300-500{ }^{\circ} \mathrm{C} \\
\mathrm{H} 2 \mathrm{O}-\mathrm{NaCl} \\
\mathrm{P}-\mathrm{T}:<100 \mathrm{MPa}, \\
<300^{\circ} \mathrm{C}\end{array}$ & $+9.6 /+11.4$ & No data & $\begin{array}{l}\text { Gold precipitation linked to mixing } \\
\text { to mixing between two distinctive } \\
\text { aqueous fluids }\end{array}$ & & $\begin{array}{l}\text { Noronha et al.(2000) } \\
\text { Vallance et al. (2003) }\end{array}$ \\
\hline & $\begin{array}{l}\text { Sb-Au veins in Cambrian metasedimentary } \\
\text { rocks }\end{array}$ & $\begin{array}{l}\text { Arsenopyrite-Pyrite-Stibnite- } \\
\text { Gold } \pm \text { sulfides and sulfosalts }\end{array}$ & $\begin{array}{l}\mathrm{H}_{2} \mathrm{O}-\mathrm{NaCl}-\mathrm{CO}_{2}-\left(\mathrm{CH}_{4}\right) \\
\text { No P data, } \mathrm{T}: 300-390^{\circ} \mathrm{C} \\
\mathrm{H}_{2} \mathrm{O}-\mathrm{NaCl} \\
\text { No P data, } \mathrm{T}: 125-225^{\circ} \mathrm{C}\end{array}$ & No data & No data & $\begin{array}{l}\text { Pb isotope data indicate a homogeneous } \\
\text { lead source of crustal origin }\end{array}$ & & Neiva et al.(2008) \\
\hline $\begin{array}{l}\text { Central/Western } \\
\text { Iberia }\end{array}$ & $\begin{array}{l}\text { Syn and postcinematic Sb-Au veins in } \\
\text { Upper Precambrian an Lower Palaeozoic } \\
\text { metasedimentary rocks }\end{array}$ & $\begin{array}{l}\text { Arse nopyrite-Pyrite-Stibnite- } \\
\text { Gold } \pm \text { sulfides and sulfosalts }\end{array}$ & $\begin{array}{l}\mathrm{H}_{2} \mathrm{O}-(\mathrm{NaCl})-\mathrm{CO}_{2}-\mathrm{CH}_{4}-\left(\mathrm{N}_{2}\right) \\
\mathrm{P}-\mathrm{T}: 150 \mathrm{MPa}, \\
300^{\circ} \mathrm{C} \\
\mathrm{H}_{2} \mathrm{O}-\mathrm{NaCl} \\
\text { No P-T data }\end{array}$ & No data & No data & $\begin{array}{l}\text { local unmixing associated to gold } \\
\text { deposition }\end{array}$ & & $\begin{array}{l}\text { Dee and Roberts (1993) } \\
\text { Murphy and Roberts (1997) } \\
\text { Ortega and Vindel (1995) }\end{array}$ \\
\hline \multirow[t]{2}{*}{$\begin{array}{l}\text { Massif Central, } \\
\text { France }\end{array}$} & $\begin{array}{l}\text { Quartz-arsenopyrite gold-quartz lenses } \\
\text { in Late Precambrian-Early Palaeozoic } \\
\text { metamorphic rocks }\end{array}$ & $\begin{array}{l}\text { Arsenopyrite-Pyrite-Gold } \\
\text { ( } \pm \text { sulfides })\end{array}$ & $\begin{array}{l}\mathrm{H}_{2} \mathrm{O}-\mathrm{NaCl}-\mathrm{CO}_{2}-\left(\mathrm{CH}_{4}-\mathrm{N}_{2}\right) \\
\mathrm{P}-\mathrm{T}: 40-120 \mathrm{MPa} \\
260-550{ }^{\circ} \mathrm{C} \\
\mathrm{H}_{2} \mathrm{O}-\mathrm{NaCl} \\
\mathrm{P}-\mathrm{T}: 40-120 \mathrm{MPa} \\
200-250^{\circ} \mathrm{C}\end{array}$ & $0 /+12.5$ & No data & $\begin{array}{l}\text { Gold precipitation in relation to dilution } \\
\text { and mixing of fluids, together a pressure } \\
\text { drop }\end{array}$ & $320-290$ & $\begin{array}{l}\text { Boiron et al.(2003) } \\
\text { Bouchot et al. (1989) } \\
\text { Bouchot et al. (2005) } \\
\text { Essaraj et al.(2001) } \\
\text { Groves et al. (1998) }\end{array}$ \\
\hline & $\begin{array}{l}\text { Quartz veins hosted by Carboniferous } \\
\text { migmatites an gneisses }\end{array}$ & $\begin{array}{l}\text { Pyrite-Arsenopyrite-(Gold)- } \\
\text { Stibnite } \pm \text { sulfides and sulfosalts }\end{array}$ & $\begin{array}{l}\mathrm{H}_{2} \mathrm{O}-\mathrm{NaCl} \\
\text { (Trace of } \mathrm{CO}_{2}-\mathrm{CH}_{4^{-}} \pm \mathrm{N}_{2} \text { ) } \\
\text { P-T: }<5 \mathrm{MPa}, 200-360^{\circ} \mathrm{C}\end{array}$ & $-1.0 /+4$ & No data & $\begin{array}{l}\text { Ore fluids characterized by an aqueous } \\
\text { composition }\end{array}$ & $310-300$ & $\begin{array}{l}\text { Bellot et al. (2003) } \\
\text { Boiron et al. (1989) } \\
\text { Bouchot et al. (2005) }\end{array}$ \\
\hline $\begin{array}{l}\text { The Bohemian } \\
\text { Massif }\end{array}$ & $\begin{array}{l}\text { Quarz-arsenopyrite-gold veinlets in } \\
\text { granodiorite }\end{array}$ & $\begin{array}{l}\text { Arsenopyrite-Pyrite-Pyrrhotite- } \\
\text { Gold ( } \pm \text { minor sulfides) }\end{array}$ & $\begin{array}{l}\mathrm{H}_{2} \mathrm{O}-\mathrm{NaCl}-\mathrm{CO}_{2}-\left(\mathrm{CH}_{4}-\mathrm{N}_{2}\right) \\
\mathrm{P}-\mathrm{T}: 120-180 \mathrm{MPa} \\
350-4500^{\circ} \mathrm{C} \\
\mathrm{H}_{2} \mathrm{O}-\mathrm{NaCl} \\
\mathrm{P}-\mathrm{T}: 20-70 \mathrm{MPa} \\
130-280^{\circ} \mathrm{C}\end{array}$ & No data & No data & $\begin{array}{l}\text { Fluids of unknown origin but equilibrated } \\
\text { with metamorphic rocks }\end{array}$ & $340-310$ & $\begin{array}{l}\text { Boiron et al. (2001) } \\
\text { Groves et al. (1998) } \\
\text { Morávek and Pouba (1990) }\end{array}$ \\
\hline
\end{tabular}


Although granites are present in the surroundings of most studied deposits, the granitoids act only as sources of heat that drive large convective hydrothermal cells along the major structures (Table 8).

Llamas de Cabrera deposits show certain differences in relation to other Variscan gold types, such as the presence of a $\mathrm{CO}_{2}-\left(\mathrm{CH}_{4}\right)$ fluid in one deposit and the absence of an Sb stage; however the major difference is the absence of granites at the surface. The ascent of some late Variscan magmatic bodies, not exposed at the present day erosion level, could be invoked as the source of heat flow to sustain the hydrothermal activity. Another peculiarity of the llamas de Cabrera veins is their consistent location in the transitional series called Rubianes Formation (quartzites, slates, and oolitic iron formation) overlying the Armorican quartzites. The reason for the relation between the gold-bearing quartz veins and this particular layer remains unknown.

As-Au hydrothermal veins such as Llamas de Cabrera are considered "deep-seated gold deposits" in the sense of Bouchot et al. (2005) developed under lithostatic to hydrostatic pressure. The majority of deposits of this style are sited in ductile to brittle structures and formed a depths from 6 to $12 \mathrm{~km}$. Gold deposits of this type in the Variscan Iberian belt are restricted to the northwest of Spain and Portugal. In contrast, SbAu deposits are classified as "shallow gold deposits" emplaced from $6 \mathrm{~km}$ to near the surface under hydrostatic pressures. The shallow type includes several deposits in northwest/central Portugal and western Spain as syn- and post-kinematic veins (Table 8 ). The absence in Llamas de Cabrera of a Sb stage is probably due to deeper formation of the As-Au veins compared to other Sb-Au veins of northern, central, and western Iberia.

\section{Acknowledgments}

This research has been funded through the research project 2005/ 103. Diputación Provincial de León. We gratefully acknowledge the contribution of Dr. A. Paniagua at the beginning of this study. H.A. Gilg and two anonymous reviewers are also thanked for their critical reviews, which helped improve the manuscript.

\section{References}

Arias, D., Corretgé, L.G., Villa, L., Gallastegui, G., Suárez, O., Cuesta, A., 1997. A sulphur isotopic study of the Navia gold belt (Spain). J. Geochem. Explor. 59, 1-10.

Bakker, R.J., 1999. Adaptation of the Bowers and Helgeson (1983) equation of state to the $\mathrm{H}_{2} \mathrm{O}-\mathrm{CO}_{2}-\mathrm{CH}_{4}-\mathrm{N}_{2}-\mathrm{NaCl}$ system. Chem. Geol. 154, 225-236.

Bakker, R.J., Jansen, J.B.H., 1991. Experimental post-entrapment water loss from synthetic $\mathrm{CO}_{2}-\mathrm{H}_{2} \mathrm{O}$ inclusions in natural quartz. Geochim. Cosmochim. Acta 55 2215-2230.

Bakker, R.J., Dubessy, J., Cathelineau, M., 1996. Improvements in clathrate modelling: I. The $\mathrm{H}_{2} \mathrm{O}-\mathrm{CO}_{2}$ system with various salts. Geochim. Cosmochim. Acta 60, 1657-1681.

Barros Lorenzo, J.C., 1989. Nuevos datos geológicos y cartográficos sobre el flanco sur del Sinclinorio de Truchas (Ourense-Ieón, NW de España). Cuadernos Iab. Xeolóxico de Laxe 14, 93-116.

Bellot, J.-P., Lerouge, C., Bailly, L., Bouchot, V., 2003. The Biards Sb-Au-bearing shear zone (Massif Central, France): an indicator of crustal-scale transcurrent tectonics guiding Late Variscan collapse. Econ. Geol. 98, 1427-1447.

Bodnar, T.S., 1993. Revised equation and table for determining the freezing point depression of $\mathrm{H}_{2} \mathrm{O}-\mathrm{NaCl}$ solutions. Geochim. Cosmochim. Acta 57, 683-684.

Boiron, M.C., Cathelineau, M., Trescases, J.J., 1989. Condition of gold-bearing arsenopyrite crystallization in the Villeranges Basin, Marche-Combrailles shear zone, France; a mineralogy and fluid inclusion study. Econ. Geol. 84, 1340-1362.

Boiron, M.C., Cathelineau, M., Banks, D.A, Yardley, B.W.D., Noronha, F., Miller, M.F., 1996. P-T-X conditions of late Hercynian fluid penetration and the origin of granite-hosted gold quartz veins in northwestern Iberia: A muldisciplinary study of fluid inclusions and their chemistry. Geochim. Cosmochim. Acta 60, 43-57.

Boiron, M.C., Barakat, A., Cathelineau, M., Banks, D.A., Durisova, J., Moravek, P., 2001. Geometry and P-V-T-X conditions of microfissural ore fluid migration: the Mokrsko gold deposit (Bohemia). Chem. Geol. 173, 207-225.

Boiron, M.C. Cathelineau, M. Banks, D. F, Fourcade, S., Vallance, J. 2003. Mixing of metamorphic and surficial during the uplift of the Hercynian upper crust: consequences of gold deposition. Chem. Geol. 194, 119-141.

Borthwick, J., Harmon, RS., 1982. A note regarding $\mathrm{CIF}_{3}$ as an alternative to $\mathrm{BrF}_{5}$ for oxygen isotope analysis. Geochim. Cosmochim. Acta 46, 1665-1668.

Bouchot, V., Gros, Y., Bonnemaison, M., 1989. Structural controls on the auriferous shear zones of the Saint Yrieix district, Massif Central, France: evidence from the Le Bourneix and Iaurieras gold deposits. Econ. Geol. 84, 1315-1327.
Bouchot, V., Ledru, P., Lerouge, C., Lescuyer, J.L., Milesi, J.-P., 2005. Late Variscan mineralizing systems related to orogenic processes: The French Massif Central. Ore Geol. Rev. 27, 169-197.

Burke, E.A.J., 2001. Raman microspectrometry of fluid inclusions. Lithos 55, 39-158.

Chi, G., Liu, Y., Dubé, B., 2009. Relationship between $\mathrm{CO}_{2}$-dominated fluids, hydrothermal alterations and gold mineralization in the Red Lake greenstone belt, Canada. Appl. Geochem. 24, 504-516.

Choi, S.G., Youm, S. J., 2000. Compositional variation of arsenopyrite and fluid evolution at the Ulsan deposit, Southeastern Korea: a low-sulfidation porphyry system. Can. Mineral. 38, 567-583.

Clayton, R.N., Mayeda, T.K., 1963. The use of bromine pentafluoride in the extraction of oxygen from oxide and silicates for isotopic analysis. Geochim. Cosmochim. Acta $27,43-52$.

Couto, H., Roger, G., Moëlo, Y., Brill, H., 1990. Le district à antimoine-or Dúrico-Beirao (Portugal): évolution paragénétique et géochimique; implications méttalogéniques. Miner. Deposita 25 (Suppl.), 569-581.

Crespo, J.L., Moro, M.C., Fadón, O., Cabrera, R., Fernandez, A., 2000. The Salamón gold deposit (León, Spain). J. Geochem. Explor. 71, 191-208.

Dee, S.J., Roberts, S., 1993. Late-kinematic gold mineralisation during regional uplift and the role of nitrogen: an example from the La Codosera area, $W$ Spain. Mineral. Mag. 57, 437-450.

Díez Montes, A, 2007. La Geología del Dominio "Ollo de Sapo" en las Comarcas de Sanabria y Tierra do Bolo. PhD Thesis Universidad de Salamanca, Serie Nova Terra 34, Instituto Universitario de Geología "Isidro Parga Pondal", Universidade da Coruña (Spain), $494 \mathrm{p}$

Díez Montes, A, Martínez Catalán, J.R., Bellido, Mulas F., 2010. Role of the Ollo de Sapo massive felsic volcanism of NW Iberia in the Early Ordovician dynamics of northern Gondwana. Gondwana Res. 17, 363-376.

Essaraj, S., Boiron, M.C., Cathelineau, M., Fourcade, S., 2001. Multistage deformation of Au-quartz veins (laurieras, French Massif Central): evidence for late gold introduction from microestructural, isotopic and fluid inclusion studies. Tectonophysics 336, 79-99.

Garba, I., Akande, S.O., 1992. The origin and significance of non-aqueous $\mathrm{CO}_{2}$ fluid inclusions in the auriferous veins of Bin Yauri, northwestern Nigeria. Miner. Deposita 27, 249-255

Gibert, F., Pascal, M.L., Pichavant, M., 1998. Gold solubility and speciation in hydrothermal solutions: experimental study of the stability of hydrosulphide complex of gold (AuHS ) at 350 to $450^{\circ} \mathrm{C}$ and 500 bars. Geochim. Cosmochim. Acta 62, 2931-2947.

Gómez-Fernández, F., Matías, R., Méndez, A. J., Cifuentes, J., 2005. Estudio preliminar de las mineralizaciones de la mina de oro romana de Llamas de Cabrera (León, NO de España). Estud. Geol. 61, 111-119.

Groves, D.L, Goldfarb, R.J., Gebre-Mariam, M., Hagemann, S.G., Robert, F., 1998. Orogenic gold deposits: a proposed classification in the context of their crustal distribution and relationship to other gold deposit types. Ore Geol. Rev. 13, 7-27.

Gutiérrez-Marco, J.C., Aramburu, C., Arbizu, M., Bernárdez, E., Hacar Rodríguez, M.P. Méndez-Bedia, I., Montesinos Iópez, R., Rábano, I., Truyols, J., Villas, E., 1999. Revi sión bioestratigráfica de las pizarras del Ordovício Medio en el Noroeste de España (Zonas Cantábrica, Asturoccidental-Leonesa y Centroibérica septentrional). Acta Geol. Hisp. 34, 3-87.

Herail, G., 1984. Géomorfologie et gitologie de l'or détritique. Piédmont et bassins intramontagneux du Nord-Ouest de l'Espagne. Centre National de la Recherche Scientifique (CNRS), Paris. (456 pp.).

Hollister, L.S., 1990. Enrichment of $\mathrm{CO}_{2}$ in fluid inclusions in quartz by removal of $\mathrm{H}_{2} \mathrm{O}$ during crystal-plastic deformation. J. Struct. Geol. 12, 895-901.

Huizenga, J.M., Touret, J.L.R., 1999. Fluid inclusions in shear zones, the case of the Umwindsishear zone in the Harare-Shamva-Binduragreenstone belt, NE Zimbabwe. Eur. J. Mineral. 11, 1079-1090.

Johnson, E.L., Hollister, L.S., 1995. Syndeformational fluid trapping in quartz: determining the pressure-temperature conditions of deformation from fluid inclusions and the formation of pure $\mathrm{CO} 2$ fluid inclusions during grain-boundary migration. J. Metamorph. Geol. 13, 239-249.

Kerestedjian, T., 1997. Chemical and morphological features of arsenopyrite, concerning its use a geothermometer. Mineral. Petrol. 60, 231-243.

Klein, E.L., Fuzikawa, K., 2010. Origin of the $\mathrm{CO}_{2}$-only fluid inclusions in the Palaeopro terozoic Carará vein-quartz gold deposit, Ipitinga Auriferous, SE-Guiana Shield Brazil: implications for orogenic gold mineralization. Ore Geol. Rev. 37, 31-40

Klein, E.L, Harris, C., Renac, C., Giret, A., Moura, C.A.V., Fuzikawa, K., 2006. Fluid inclusion and stable isotope $(\mathrm{O}, \mathrm{H}, \mathrm{C}$ and $\mathrm{S})$ constraints on the genesis of the Serrinha gold deposit, Gurupi Belt, Northern Brazil. Miner. Deposita 41, 160-178.

Kretschmar, U., Scott, S.D., 1976. Phase relations involving arsenopyrite in the system Fe-As-S and their application. Can. Mineral. 14, 364-386.

Marcos, A., 1973. Ias series del Paleozoico Inferior y la estructura herciniana del occidente de Asturias (NW de España). Trabajos de Geología, 6. Facultad de Ciencias. Universidad de Oviedo, pp. 1-113.

Martínez Catalán, J.R., Hacar Rodríguez, M.P., Villar Alonso, P., Pérez Estaún, A González Lodeiro, F., 1992. Lower Paleozoic extensional tectonics in the limit between the West Asturian-Leonese and Central Iberian Zones of the Variscan Fold Belt in NW Spain. Geol. Rundsch. 81, 545-560.

Matias, R., Gómez-Fernández, F., 2003. La mina romana de Llamas de Cabrera (LeónEspaña). IV Congreso Internacional sobre Patrimonio Geológico y Minero, Utrillas (Teruel), pp. 383-398.

Morávek, P., Pouba, Z., 1990. L'or dans la métallogenie de Bohéme. Miner. Deposita 25 (Suppl.), 90-98.

Murphy, P.J., Roberts, S., 1997. Evolution of a metamorphic fluid and its role in lode gold mineralization in the Central Iberian Zone. Miner. Deposita 32, 459-474. 
Neiva, A.M.R., Andráš, P., Ramos, J.M.F., 2008. Antimony quartz and antimony-gold quartz veins from northern Portugal. Ore GeoL Rev.34, 533-546.

Noronha, F., Cathelineau, M., Boiron, M.-C., Banks, D.A., Dória, A., Ribeiro, M.A. Nogueira, P., Guedes, A., 2000. A three stage fluid flow model for Variscan gold metallogenesis in northern Portugal. J. Geochem. Explor. 71, 209-224.

Ohmoto, H., Rye, R.O., 1979. Isotopes of sulphur and carbon. In: Barnes, H.L. (Ed.), Geochemistry of Hydrothermal Ore Deposits. Wiley, New York, pp. 509-567.

Ortega Cuesta, L.A., Aranguren, A., Menéndez, M., Gil Ibarguchi,J.L, 2000a. Petrogénesis, edad y emplazamiento granítico del granito tardi-Hercínico de Veiga (antiforme del Ollo de Sapo, Noroeste de España). Cuadernos Lab. Xeolóxico de Laxe 25, 265-268.

Ortega Cuesta, L.A., Aranguren, A., Menéndez, M., Gil Ibarguchi,J.L, 2000b. Petrogenesis, age and emplacement of the late-Hercinian Veiga granite (Ollo de Sapo antiform, Northwestern Spain). Variscan-Apalachian dynamics, the building of the Upper Paleozoic basement. Basement Tectonics 15, A Coruña, España, Program and Abstracts, pp. 271-272.

Ortega, L., Vindel, E., 1995. Evolution of ore-f orming fluids associated with late Hercynian antimony deposits in central/western Spain: case study of Mari Rosa and El Juncalón. Eur. J. Mineral. 7, 655-673.

Pérez-Estaún, A., 1975. La estratigrafía y la estructura de la rama Sur de la Zona Asturoccidental-Leonesa ( $W$ de León, NW de España). PhD Thesis. Universidad de Oviedo, Spain.

Pérez-Estaún, A., Bea, F., Bastida, F., Marcos, A., Martínez Catalán, J.R., Martínez Poyatos, D., Arenas, R, Díaz García, F., Azor, A., Simancas, J.F., González Iodeiro, F., 2004. La Cordillera Varisca Europea: el Varisco Ibérico. In: Vera, J.A. (Ed.), Geología de España. SGE-IGME, Madrid, pp. 21-228.

Pérez-García, L.C., Sánchez-Palencia, F.J., Torres-Ruiz, J., 2000. Tertiary and Quaternary alluvial gold deposits of Northwest Spain and Roman mining (NW of Duero and Bierzo Basins). J. Geochem. Explor. 71, 225-240.

Ribera, F., Tornos, F., Locutura, J., 1992. Las mineralizaciones hidrotermales de oro de la vertiente norte de Teleno (León). Actas III Congr. España 3, 418-421.

Robinson, B., Kusakabe, M., 1975. Quantitative preparation of sulphur dioxide for ${ }^{34} \mathrm{~S} /{ }^{32} \mathrm{~S}$ analyses from sulphides by combustion with cuprous oxide. Anal. Chem 47 , $1179-1181$.

Rodríguez Fernández, L.R., Abril Hurtado, J., Pliego Dones, D., \& Rubio Navas, J., 1982. Mapa Geológico de España E. 1:50.000, Segunda Serie. Servicio Publicaciones del Ministerio de Industria y Energía, Memoria 56 p.
Roedder, E., 1984. Fluid inclusions. Rev. Mineral. 12 (644 pp.).

Sánchez-Palencia, F.J., 1983. La explotación del oro de Asturia y Gallaecia en La Antigüedad, $\mathrm{PhD}$ Thesis, Univ. Complutense, Madrid.

Sharp, Z.D., 1990. A laser-based microanalytical method for the in situ determination of oxygen isotope ratios of silicates and oxides. Geochim. Cosmochim. Acta 54, 1353-1357.

Sharp, Z.D., Essene, E.J., Kelly, W.C, 1985. A re-examination of the arsenpyrite geothermometer: pressure considerations and applications to natural assemblages. Can. Mineral. 23, 517-534

Shepherd, T.J., 1981. Temperature programable heating-f reezing stage for microthermometric analysis of fluid inclusions. Econ. GeoL 76, 1244-1247.

Sheppard, S.M.F., 1986. Characterization and isotopic variations in natural waters: in: stable isotopes in high temperature geological processes. In: Valley, J.W., Taylor, H.P., O'Neill, J.R. (Eds.), Stable Isotopes in High Temperature Geological Processes: Reviews in Mineralogy, 16, pp. 165-184.

Thiery, R., Vidal, J., Dubessy, J., 1994. Phase equilibria modelling applied to fluid inclusions liquid-vapour equilibria and calculation of the molar volume in the $\mathrm{CO}_{2}-$ $\mathrm{CH}_{4}-\mathrm{N}_{2}$ system. Geochim. Cosmochim. Acta 58, 1073-1082.

Tornos, F., Spiro, B., Shepherd, T.J., Ribera, F., 1997. Sandstone-hosted gold lodes of the southern West Asturian Leonese zone (NW Spain). Chron. Rech. Min. 528, 71-86.

Vallance, J., Cathelineau, M., Boiron, M.C., Fourcade, S., Shepherd, T.J., Naden, J., 2003. Fluid-rock interactions and the role of late Hercynian aplite intrusion in the genesis of the Castromil gold deposit, northern Portugal. Chem. GeoL 194, 201-224.

Vityk, M.O., Bodnar, R.J., 1995. Textural evolution of synthetic fluid inclusions in uartz during reequilibration, with applications to tectonic reconstruction. Contrib. MineraL Petrol. 121, 309-323.

Wille, S.E., Klemd, R., 2004. Fluid inclusion studies of the Abawo gold prospect, near the Ashanti Belt, Ghana. Miner. Deposita 39, 31-45.

Zhang, Y., Frantz, D., 1987. Determination of the homogenisation temperatures and densities of supercritical fluids in the system $\mathrm{NaCl}-\mathrm{KCl}-\mathrm{CaCl}_{2}-\mathrm{H}_{2} \mathrm{O}$ using synthetic fluid inclusions. Chem. GeoL 64, 335-350.

Zheng, Y.D., 1993. Calculation of oxygen isotope fractionation in anhydrous silicate minerals. Geochim Cosmochim Acta 57, 1079-1091. 